\title{
Trans-Modulation of the Somatostatin Type 2A Receptor Trafficking by Insulin-Regulated Aminopeptidase Decreases Limbic Seizures
}

\author{
Dimitri De Bundel, ${ }^{1 \star}$ Assia Fafouri, ${ }^{2,3 *}$ Zsolt Csaba, ${ }^{2,3 *}$ Ellen Loyens, ${ }^{1}$ Sophie Lebon, ${ }^{2,3}$ Vincent El Ghouzzi, ${ }^{2,3}$ \\ Stéphane Peineau, ${ }^{2,3,4}$ Guilan Vodjdani, ${ }^{2,3}$ Foteini Kiagiadaki, ${ }^{5}$ Najat Aourz, ${ }^{1}$ Jessica Coppens, ${ }^{1}$ Laura Walrave, ${ }^{1}$ \\ Jeanelle Portelli, ${ }^{1}$ Patrick Vanderheyden, ${ }^{6}$ Siew Yeen Chai, ${ }^{7}$ Kyriaki Thermos, ${ }^{5}$ Véronique Bernard, ${ }^{8}$ \\ [-Graham Collingridge, ${ }^{4}$ Stéphane Auvin, ${ }^{2,3}$-Pierre Gressens, ${ }^{2,3}$ Ilse Smolders, ${ }^{1} \dagger$ and Pascal Dournaud ${ }^{2,3} \dagger$ \\ ${ }^{1}$ Department of Pharmaceutical Chemistry and Drug Analysis, Center for Neurosciences, Vrije Universiteit Brussel, 1090 Brussels, Belgium, ${ }^{2}$ Inserm, \\ U1141, 75019 Paris, France, ${ }^{3}$ University Paris Diderot, Sorbonne Paris Cité, UMR1141, 75019 Paris, France, ${ }^{4}$ MRC Centre for Synaptic Plasticity, School of \\ Physiology and Pharmacology, University of Bristol, Bristol BS8 1TD, United Kingdom, ${ }^{5}$ Laboratory of Pharmacology, Faculty of Medicine, University of \\ Crete, Heraklion 71003, Greece, ${ }^{6}$ Department of Molecular and Biochemical Pharmacology, Vrije Universiteit Brussel, 1090 Brussels, Belgium, ${ }^{7}$ Department \\ of Physiology, Monash University, Victoria 3052, Australia, and ${ }^{8}$ Inserm U952, CNRS UMR7224, Université Pierre et Marie Curie, 75005 Paris, France
}

Within the hippocampus, the major somatostatin (SRIF) receptor subtype, the sst2A receptor, is localized at postsynaptic sites of the principal neurons where it modulates neuronal activity. Following agonist exposure, this receptor rapidly internalizes and recycles slowly through the trans-Golgi network. In epilepsy, a high and chronic release of somatostatin occurs, which provokes, in both rat and human tissue, a decrease in the density of this inhibitory receptor at the cell surface. The insulin-regulated aminopeptidase (IRAP) is involved in vesicular trafficking and shares common regional distribution with the sst $2 \mathrm{~A}$ receptor. In addition, IRAP ligands display anticonvulsive properties. We therefore sought to assess by in vitro and in vivo experiments in hippocampal rat tissue whether IRAP ligands could regulate the trafficking of the sst2A receptor and, consequently, modulate limbic seizures. Using pharmacological and cell biological approaches, we demonstrate that IRAP ligands accelerate the recycling of the sst2A receptor that has internalized in neurons in vitro or in vivo. Most importantly, because IRAP ligands increase the density of this inhibitory receptor at the plasma membrane, they also potentiate the neuropeptide SRIF inhibitory effects on seizure activity. Our results further demonstrate that IRAP is a therapeutic target for the treatment of limbic seizures and possibly for other neurological conditions in which downregulation of G-protein-coupled receptors occurs.

Key words: GPCR; insulin-regulated aminopeptidase; limbic seizures; neuropeptide; somatostatin; traffic

Significance Statement

The somatostatin type $2 \mathrm{~A}$ receptor (sst2A) is localized on principal hippocampal neurons and displays anticonvulsant properties. Following agonist exposure, however, this receptor rapidly internalizes and recycles slowly. The insulin-regulated aminopeptidase (IRAP) is involved in vesicular trafficking and shares common regional distribution with the sst2A receptor. We therefore assessed by in vitro and in vivo experiments whether IRAP could regulate the trafficking of this receptor. We demonstrate that IRAP ligands accelerate sst $2 \mathrm{~A}$ recycling in hippocampal neurons. Because IRAP ligands increase the density of sst $2 \mathrm{~A}$ receptors at the plasma membrane, they also potentiate the effects of this inhibitory receptor on seizure activity. Our results further demonstrate that IRAP is a therapeutic target for the treatment of limbic seizures.

\section{Introduction}

The somatostatin (SRIF) type 2A receptor (sst2A) mediates SRIF inhibitory effects on cell excitability (Peineau et al., 2003; Olias et al., 2004; Bassant et al., 2005) and displays anticonvulsant properties (Vezzani and Hoyer, 1999; Tallent and Qiu, 2008; Clynen et al., 2014; Dobolyi et al., 2014). Like many GPCRs, sst2A receptors 
rapidly internalize (Dournaud et al., 1998; Csaba et al., 2001, 2003, 2012; Stumm et al., 2004) and are then specifically targeted to a perinuclear/trans-Golgi network (TGN) compartment, bypassing the late endosomal compartment and the degradative pathway (Csaba et al., 2007; Lelouvier et al., 2008). Afterward, they slowly recycle to the plasma membrane of both cell bodies and dendrites. Interestingly, this particular recycling route undertaken by the sst $2 \mathrm{~A}$ receptor shares common pathways with the glucose transporter 4 (GLUT4) (Leto and Saltiel, 2012). A key regulator of GLUT4 storage vesicles is the insulin-regulated aminopeptidase (IRAP), a Type II membrane protein (Chai et al., 2004; Albiston et al., 2007; Vanderheyden, 2009; Wright and Harding, 2011). In the basal state, IRAP is located principally in an intracellular compartment with GLUT4, and these proteins move to the cell surface identically in response to insulin (Keller, 2003). In addition to its aminopeptidase activity involved in peptide hormone processing, IRAP also acts as a receptor for the endogenous ligands angiotensin IV (Ang IV) and LVVHemorphin 7 (LVV-H7). IRAP ligands are on the one hand competitive inhibitors of the enzymatic activity of IRAP and on the other hand regulators of its trafficking (Albiston et al., 2007). The extracellular part of IRAP contains the aminopeptidase activity, whereas its intracellular domain interacts with cytosolic proteins that contribute to GLUT4 vesicle retention and translocation to the plasma membrane; however, the mechanisms involved in this latter process remain to be demonstrated (Albiston et al., 2007).

Although the memory- and cognitive-enhancing effects of IRAP ligands are well established (Albiston et al., 2003, 2011), the role of IRAP in the CNS is yet to be fully elucidated. Most interestingly, IRAP ligands display anticonvulsive activities in different animal models (Tchekalarova et al., 2001, 2004; Stragier et al., 2006; Loyens et al., 2011). In accordance with these central actions, IRAP was found to be highly expressed in brain areas associated with cognition and epilepsy (Fernando et al., 2005), regions that also displayed the highest densities of sst2A receptor immunoreactivity (Dournaud et al., 1996, 1998; Schindler et al., 1997). At the cellular level, IRAP immunoreactivity in neurons is associated with the trans-Golgi apparatus and vesicular structures in the proximity of the Golgi cisternae (Fernando et al., 2007), a location remarkably comparable with that of internalized sst2A receptors before recycling (Csaba et al., 2007; Lelouvier et al., 2008). Because IRAP shares common distribution with the sst $2 \mathrm{~A}$ receptor and is involved in vesicular trafficking, we sought to assess by in vitro and in vivo experiments whether IRAP could regulate the trafficking of the sst $2 \mathrm{~A}$ receptor and, consequently, modulate its anticonvulsant actions.

This work was supported by Inserm to P.G. and P.D., Paris Diderot University to P.G. and P.D., La Fondation pour la Recherche sur le Cerveau to P.D., the PremUP Foundation to P.G., the Seventh Framework Program of the European Union Grant Agreement HEALTH-F2-2009-241778/Neurobid to P.G., Assistance Publique-Hôpitaux de Paris (Contrat de Recherche Translationnelle to P.D. and P.G. and Contrat de Recherche Hospitalier to S.A.), the Fund for Scientific Research FWO Flanders Grants G.0165.08 and G.0163.10N to I.S., the Queen Elisabeth Medical Foundation GSKE to I.S., and the Research Council of the Vrije Universiteit Brussel Grants 0ZR1943, 0ZR1443, and GOA61 to I.S. and D.D.B., S.P. was supported by the Medical Research Council. G.C. is a World Class University International Scholar and supported by the World Class University program through the Korea Science and Engineering Foundation, funded by the Korean Ministry of Education, Science and Technology Grant R31-10089. We thank Andrée Rouche (Inserm U974, Institut de Myologie, Hôpital Pitié-Salpêtrière, Paris, France) for electron microscopy facilities; and Gino De Smet for excellent technical assistance with microdialysis experiments and intrahippocampal EEG recordings.

The authors declare no competing financial interests.

${ }^{*}$ D.D.B., A.F., and Z.C. contributed equally to this work.

†I.S. and P.D. jointly supervised this work.

Correspondence should be addressed to Dr. Pascal Dournaud, Inserm U1141, Hôpital Robert Debré, 48 Boulevard Sérurier, 75019 Paris, France. E-mail: pascal.dournaud@inserm.fr.

DOI:10.1523/JNEUROSCI.0476-15.2015

Copyright $\odot 2015$ the authors $\quad 0270-6474 / 15 / 3511961-16 \$ 15.00 / 0$

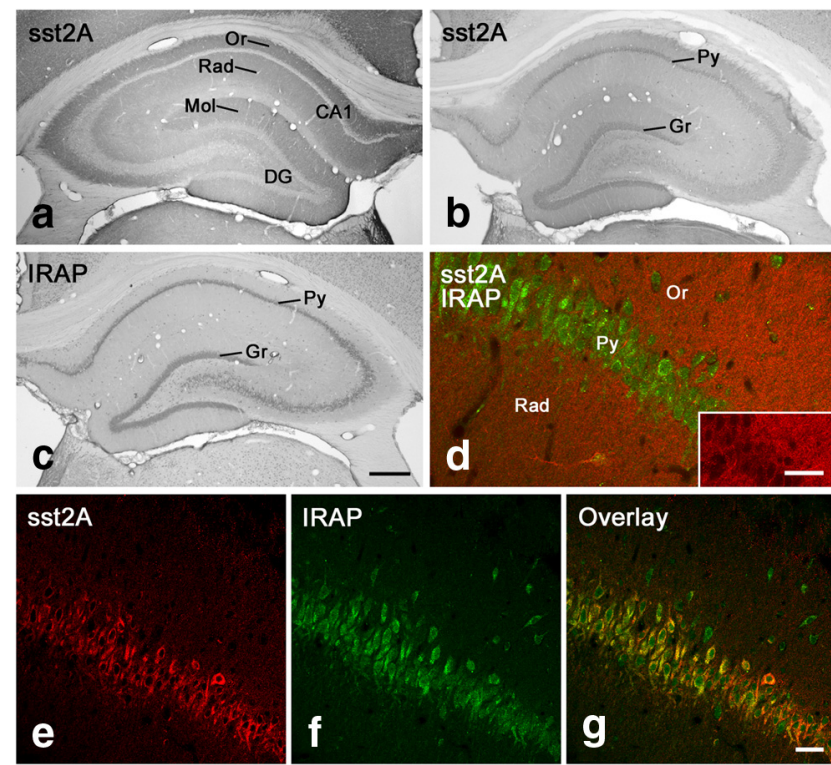

Figure 1. Neurons expressing the sst2A receptor also display IRAP immunoreactivity in the rat hippocampal formation. $\boldsymbol{a}$, In control rats, diffuse sst2A receptor immunoreactivity is observed in the strata oriens (Or) and radiatum (Rad) of CA1-3 and the molecular layer (Mol) of dentate gyrus (DG). $\boldsymbol{b}$, After intrahippocampal injection of 0 CT, sst2A receptor-immunoreactive neurons are detected in the pyramidal cell layer (Py) of CA1-3 and granular layer (Gr) of DG. c IRAP immunoreactivity is located in the principal cell layers of the hippocampal formation. $\boldsymbol{d}$, In the CA1 of control rats, double-labeling immunohistochemistry reveals that IRAP is predominantly localized in pyramidal cell bodies (Py), whereas sst2A receptor immunoreactivity is diffusely distributed in strata oriens (Or) and radiatum (Rad). Inset, sst2A receptor immunoreactivity in the pyramidal cells layer. $\boldsymbol{e}-\boldsymbol{g}$, In 0CT-injected rats, double-labeling immunohistochemistry reveals colocalization of internalized sst2A receptor and IRAP in pyramidal neurons of CA1. All hippocampal sst2A receptor-immunoreactive neurons are IRAP-positive. Only a subpopulation of IRAP-immunoreactive neurons is sst2A receptor-positive. Similar stainings were found in three different 0 CT-injected rats (three sections per animal). Scale bars: $\boldsymbol{a}-\boldsymbol{c}$, $400 \mu \mathrm{m} ; \boldsymbol{d}-\boldsymbol{g}, 40 \mu \mathrm{m}$.

\section{Materials and Methods}

Animals. Experimental procedures were performed using adult male Wistar rats (Charles River Laboratories). All efforts were made to reduce the number of animals used, and any distress caused by the procedures is in accordance with the European Communities Council Directive of September 22, 2010 (2010/63/UE) and complying with the guidelines of Inserm, the ethics committees on animal experiments of Paris Diderot University, the Vrije Universiteit Brussel, and the University of Crete. Accordingly, the number of animals in our study was kept to the necessary minimum.

Antibodies. The endogenous sst $2 \mathrm{~A}$ receptor was immunolocalized using a rabbit monoclonal antibody (3582-1, Epitomics; $1: 1000)$. This antibody is directed toward residues 355-369 of the human sst2A receptor. This sequence is identical in mouse, rat, and human sst2A. Endogenous IRAP was detected using a mouse monoclonal antibody (9876-3E1, Cell Signaling Technology; 1:200) directed against a fusion protein corresponding to the amino terminus of rat IRAP. A sheep polyclonal antibody was used to detect the TGN-specific integral membrane protein (TGN38) (PA1-84496, Thermo Scientific; 1:800). Secondary antibodies used were AlexaFluor-488 (A488)-conjugated donkey anti-rabbit (1:500; Invitrogen) or cyanine 3 (Cy3)-conjugated donkey anti-rabbit (1:500; Jackson ImmunoResearch Laboratories), Cy3-conjugated donkey antimouse (1:500; Jackson ImmunoResearch Laboratories), or A488conjugated donkey anti-mouse (1:500; Invitrogen), and AlexaFluor-633 (A633)-conjugated donkey anti-sheep (1:500; Invitrogen) to immunolocalize sst2A receptor, IRAP, and TGN38, respectively. For chromogenic detection of sst2A receptor and IRAP, biotinylated goat anti-rabbit and anti-mouse antibodies (1:300, Vector Laboratories) were used, respectively. 

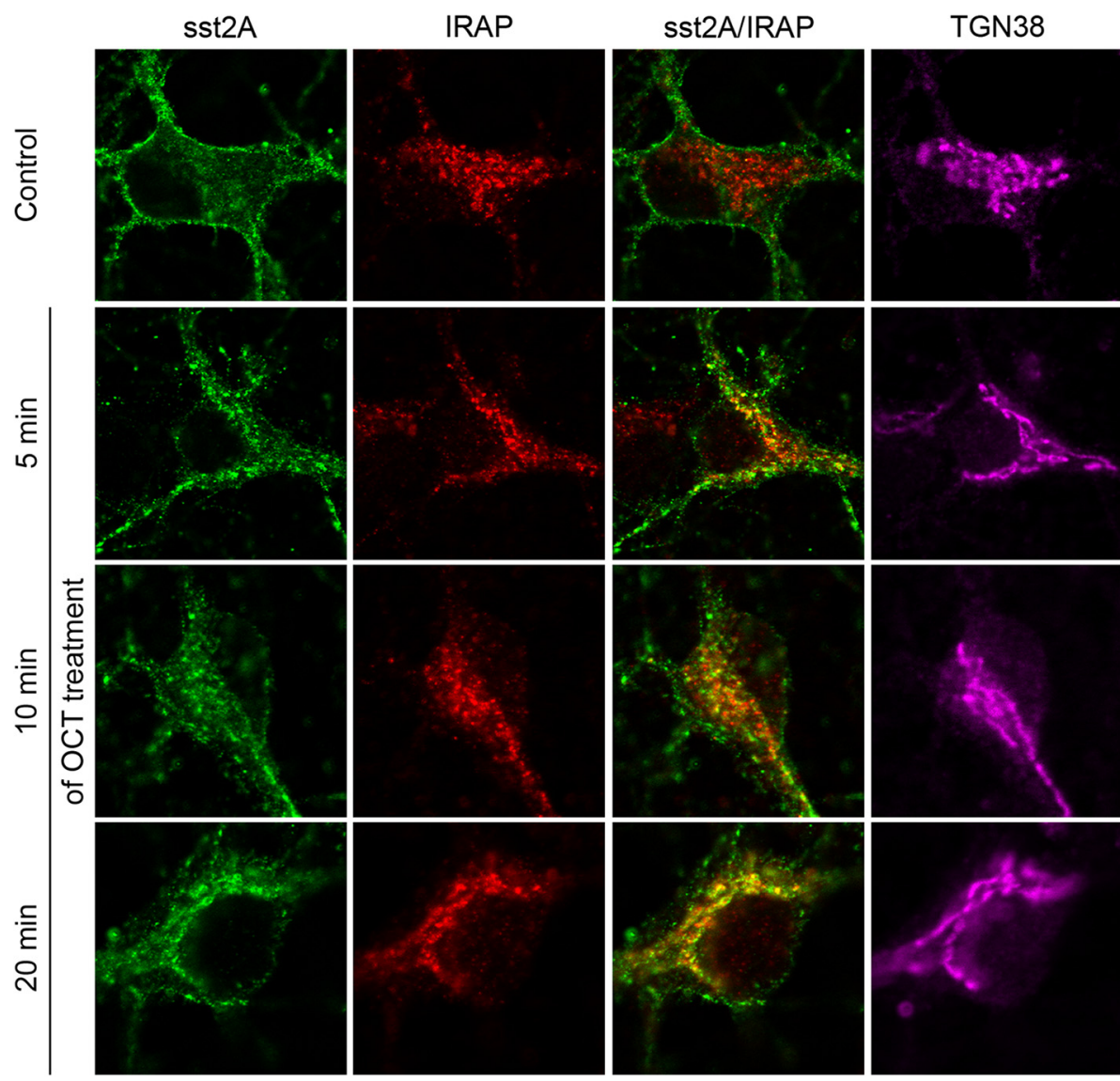

sst2A/IRAP/TGN38
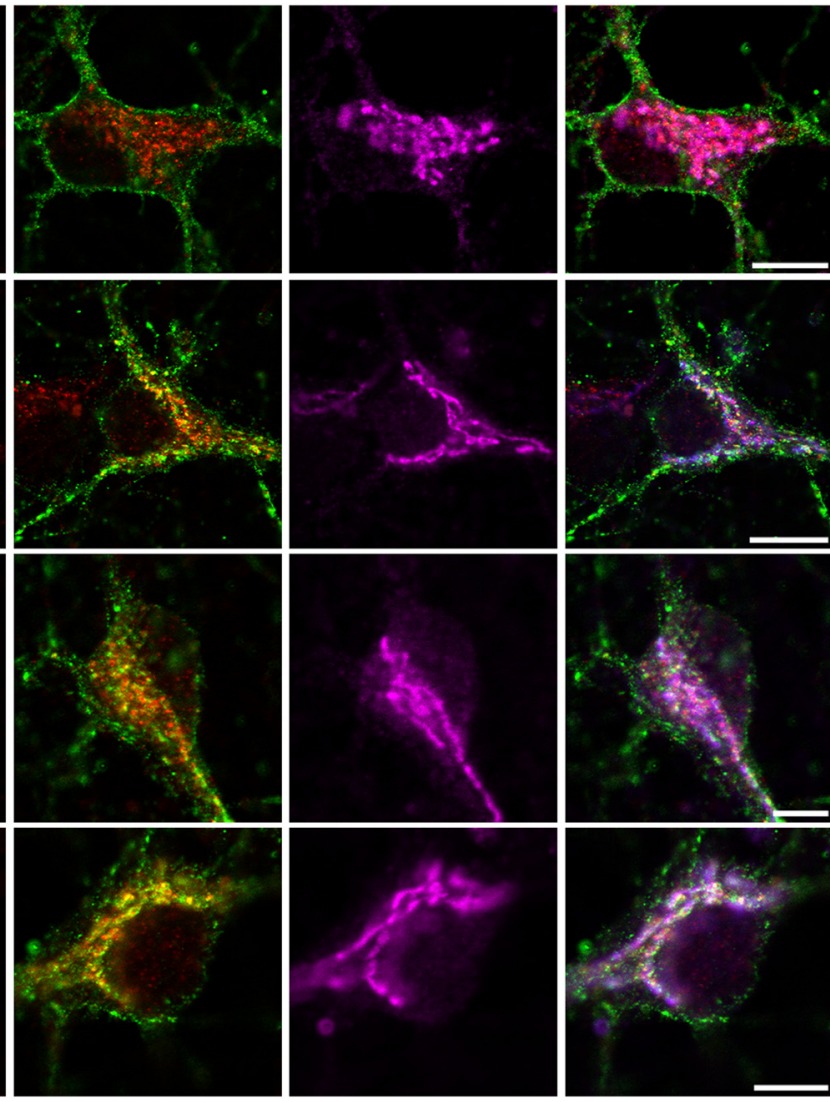

Figure 2. Kinetics of sst2A receptor internalization in primary hippocampal neurons. In control neurons, the sst2A receptor immunoreactivity is predominantly located at the surface of perikarya and proximal dendrites. Conversely, IRAP immunofluorescence is mainly confined to intracellular vesicles overlapping with TGN38. Little colocalization is thus observed between sst2A receptor and IRAP. Treatment with the sst2A receptor agonist octreotide for 5, 10, or 20 min results in a massive redistribution of sst2A receptor immunoreactivity from the cell surface into intracellular vesicles, where it is colocalized with IRAP (yellow pseudocolor signal on sst2A/IRAP merged images) and TGN38 (white pseudocolor signal on sst2A/IRAP/TGN38 merged images). Thirty neurons/group were analyzed from three independent experiments. Scale bars, $10 \mu \mathrm{m}$.

Stereotaxic injection of octreotide. Rats under isoflurane anesthesia were mounted on a stereotaxic frame and injected into the dorsal hippocampus (coordinates: $2.8 \mathrm{~mm}$ posterior; $1.4 \mathrm{~mm}$ lateral; $3.2 \mathrm{~mm}$ ventral from bregma) with octreotide (OCT; gift from Novartis Pharma AG) as previously described (Csaba et al., 2007). After $3 \mathrm{~h}$ of survival, rats were deeply anesthetized with sodium pentobarbital (60 mg/kg i.p.) and perfused through the ascending aorta with $400 \mathrm{ml}$ of $4 \%$ PFA in $0.1 \mathrm{M}$ phosphate buffer, $\mathrm{pH} 7.4(\mathrm{~PB})$. Brains were cryoprotected, frozen in liquid isopentane at $-45^{\circ} \mathrm{C}$, and sectioned in the coronal plane at a thickness of $30 \mu \mathrm{m}$ as previously described (Csaba et al., 2007).

Immunohistochemistry. Brain sections at the level of the dorsal hippocampus were selected for chromogenic and immunofluorescent labeling. For chromogenic labeling, endogenous peroxidase activity was first quenched by $0.3 \% \mathrm{H}_{2} \mathrm{O}_{2}$ in $0.01 \mathrm{M}$ PBS, $\mathrm{pH} 7.4$, for $30 \mathrm{~min}$ at room temperature (RT), washed in PBS, incubated in PBS with 5\% normal goat serum (NGS; Sigma-Aldrich) and 0.3\% Triton X-100 for $30 \mathrm{~min}$ at RT, incubated with primary antibodies diluted in PBS with $1 \%$ NGS and $0.3 \%$ Triton X-100 overnight at RT, rinsed in PBS, incubated in biotinylated secondary antibodies diluted in PBS with $3 \%$ NGS and $0.3 \%$ Triton X-100 for $1 \mathrm{~h}$ at RT, washed in PBS, and incubated in avidinbiotinylated HRP complex (ABC; Vector Laboratories) diluted in PBS for $90 \mathrm{~min}$ at RT. Peroxidase activity was revealed with $0.05 \%$ of DAB (Sigma-Aldrich) in $0.05 \mathrm{M}$ Tris buffer, pH 7.6 (TB), in the presence of hydrogen peroxide $(0.0048 \%)$. The reaction was stopped by several washes in TB. Sections were mounted on gelatin-coated slides, dehydrated in graded ethanols, delipidated in xylene, and coverslipped with Permount (Fisher Scientific) for light microscopic observation. For immunofluorescent labeling, sections were preincubated in PBS with 5\% normal donkey serum (NDS, Sigma-Aldrich) and 0.3\% Triton X-100 for
30 min at RT, incubated in primary antibodies diluted in PBS with $1 \%$ NDS and $0.3 \%$ Triton X-100 overnight at RT, rinsed in PBS, and incubated in fluorescent secondary antibodies diluted in PBS with 3\% NDS and $0.3 \%$ Triton X-100 for $1 \mathrm{~h}$ at RT. Finally, sections were rinsed in PBS, mounted on glass slides, and coverslipped with Fluoromount (Southern Biotech) for confocal microscopic analysis.

Hippocampal cell cultures. Hippocampi were dissected from 18-dayold embryo Wistar rat brains and dissociated in HBSS with $0.25 \%$ trypsin and $0.1 \%$ DNase 1 . Hippocampal neurons were plated on glass coverslips previously coated with gelatin and poly-L-lysine. Neurons were grown in Neurobasal medium (Invitrogen) supplemented with B27 and glutamine (Invitrogen) and maintained in an incubator at $37^{\circ} \mathrm{C}$ in a $95 \%$ air $/ 5 \%$ $\mathrm{CO}_{2}$ humidified atmosphere. All experiments were performed at $12-13 \mathrm{~d}$ in vitro.

In vitro pharmacological treatment. For time course experiments of sst $2 \mathrm{~A}$ receptor internalization, neurons were treated with $1 \mu \mathrm{M}$ of the sst2A receptor agonist OCT in Neurobasal medium for 5, 10, 15, and 20 $\mathrm{min}$ at $37^{\circ} \mathrm{C}$. For time course experiments of sst $2 \mathrm{~A}$ receptor recycling, neurons were pretreated with $1 \mu \mathrm{M}$ Ang IV (or PBS as control) in Neurobasal medium for $60 \mathrm{~min}$ at $37^{\circ} \mathrm{C}$, followed by addition of $1 \mu \mathrm{M}$ OCT or SRIF (Sigma-Aldrich) for $20 \mathrm{~min}$. After rinsing, neurons were treated with $1 \mu \mathrm{M}$ Ang IV (or PBS as control) in Neurobasal medium for 15, 30, $45,60,120$, and $180 \mathrm{~min}$ at $37^{\circ} \mathrm{C}$. Additional control conditions included neurons pretreated with $1 \mu \mathrm{M}$ Ang IV (or PBS) without subsequent OCT or SRIF treatment (Control without OCT; Control without agonist). At the end of incubation times, neurons were fixed with 4\% PFA supplemented with $4 \%$ sucrose in PB for 20 min at RT.

shRNA lentiviral transduction. Rat IRAP expression was inhibited in cultured hippocampal cells using SMART vector 2.0 PGK-TurboGFP 


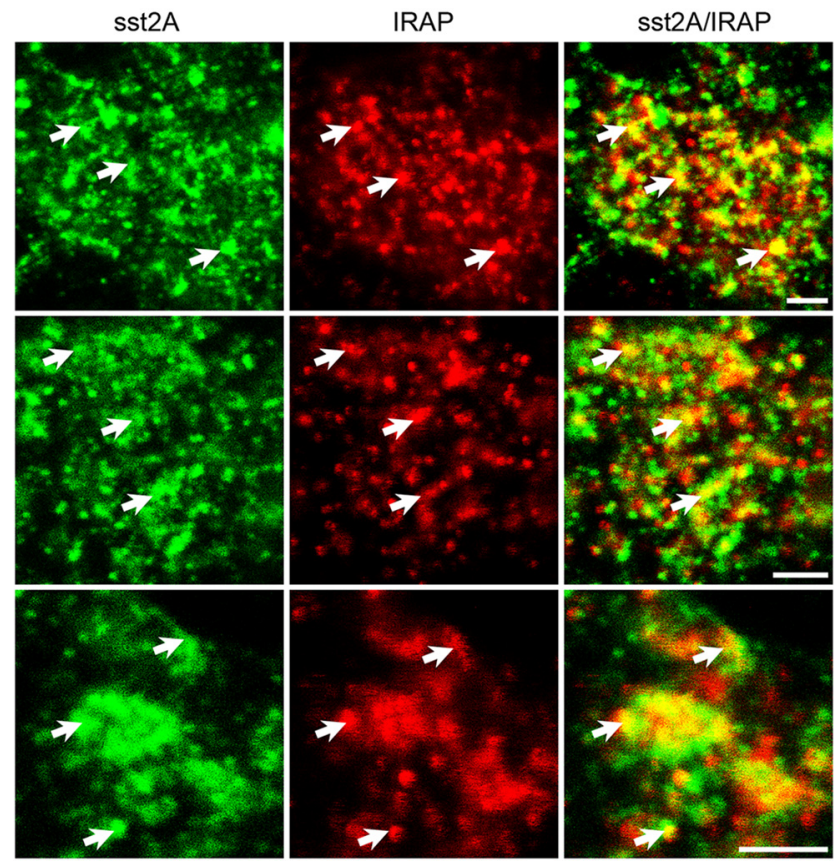

Figure 3. Internalized sst2A receptor colocalizes with IRAP in primary hippocampal neurons. The sst $2 \mathrm{~A}$ receptor immunoreactivity is confined to bright fluorescent granules in the cytoplasm of octreotide-treated neurons and colocalizes with IRAP-positive vesicles (arrows) as illustrated by high-resolution confocal microscopy in three different neurons. Scale bars, $2 \mu \mathrm{m}$.

shRNA particles according to the manufacturer's protocols (Thermo Scientific, Dharmacon). Three predesigned individual IRAP genespecific shRNA lentiviral particles were obtained from Dharmacon and provided as ready-to-use lentiviral particles (SH06-093146-01-10, SH06-093146-02-10, and SH06-093146-03-10). The shRNA target sequences were as follows: IRAP LV-shRNA1: GATTGCTACAAACGGGAAA; IRAP LV-shRNA2: AAGTTGGAGCAAGAACCGA; and IRAP LV-shRNA3: GATTAGTGACCAGAGTACA. SMART vector 2.0 Nontargeting PGK-Turbo GFP particles (S06-0050000-01) were used as control (NT LV-shRNA; TGGTTTACATGTTGTGTGA). Hippocampal cells were transduced immediately after dissociation for $1 \mathrm{~h}$ at $37^{\circ} \mathrm{C}$ (at a multiplicity of infection of 10) and used for sst2A receptor recycling experiments at $12-13 \mathrm{~d}$ in vitro. Based on TurboGFP expression, neuronal efficiency of transduction was $38.3 \%$ for the IRAP LV-shRNA1, $32.3 \%$ for the IRAP LV-shRNA2, 49.1\% for the IRAP LV-shRNA3, and $45.0 \%$ for the NT LV-shRNA.

Immunocytochemistry. Cells were washed in PBS and incubated $30 \mathrm{~min}$ in PBS with 5\% NDS and $0.1 \%$ Triton X-100. Primary antibodies were diluted in PBS with $1 \%$ NDS and $0.1 \%$ Triton X-100 and incubated overnight at $4^{\circ} \mathrm{C}$. Neurons were washed in PBS and subsequently incubated with secondary antibodies diluted in PBS with 1\% NDS and $0.1 \%$ Triton X-100 for $1 \mathrm{~h}$ at RT. Finally, coverslips were washed in PBS and mounted with Fluoromount (Southern Biotech) for confocal microscopic analysis.

Confocal microscopy. Immunofluorescent sections were analyzed using a Leica TCS SP8 confocal scanning system (Leica Microsystems) equipped with $488 \mathrm{~nm} \mathrm{Ar}, 561 \mathrm{~nm}$ DPSS, and $633 \mathrm{~nm}$ HeNe lasers or a Zeiss LSM 5 Exciter confocal scanning system (Carl Zeiss) with $488 \mathrm{~nm}$ $\mathrm{Ar}, 543 \mathrm{~nm} \mathrm{HeNe}$, and $633 \mathrm{~nm} \mathrm{HeNe}$ lasers. Eight-bit digital images were collected from a single optical plane using a $63 \times$ HC PL APO CS2 oilimmersion Leica objective (numerical aperture 1.40) or a $63 \times$ PlanApochromat oil-immersion Zeiss lens (numerical aperture 1.4). For each optical section, double- or triple-fluorescence images were acquired in sequential mode to avoid potential contamination by linkage-specific fluorescence emission cross talk. Settings for laser intensity, beam expander, pinhole (1 Airy unit), range property of emission window, electronic zoom, gain and offset of photomultiplicator, field format, and scanning speed were optimized initially and held constant throughout the study so that all sections were digitized under the same conditions.

Quantitative analysis of immunofluorescence. To assess the extent of IRAP knockdown, images of IRAP immunofluorescence from neuronal cell bodies were collected from a single optical plane using a $63 \times$ PlanApochromat oil-immersion Zeiss lens (numerical aperture 1.4). Images were segmented using identical threshold values, and integrated signal density was measured using the ImageJ software (Rasband, W.S., ImageJ, National Institutes of Health; http://imagej.nih.gov/ij/, 1997-2014). This parameter, corresponding to the intensity of the immunofluorescence staining, was measured in an average of 30 neurons/group from three independent experiments. Mean values for the four experimental groups (IRAP LV-shRNA1-3 constructs and NT LV-shRNA control) were calculated and statistically analyzed.

To quantify sst $2 \mathrm{~A}$ receptor immunoreactivity at the plasma membrane, images of sst2A receptor and TGN38 immunofluorescence from neuronal cell bodies were acquired from a single optical plane using a $63 \times$ Plan-Apochromat oil-immersion Zeiss lens (numerical aperture 1.4). The $z$-axis level was selected where the TGN38-labeled trans-Golgi network was clearly identified and the sst $2 \mathrm{~A}$ receptor labeling at the plasma membrane was identified as a line-like ring in the green channel around the TGN38 labeling of the red channel (see Fig. $6 a$ ). A 1- $\mu$ m-wide band containing the line-like sst $2 \mathrm{~A}$ receptor labeling was defined, and the average pixel intensity, corresponding to the intensity of the immunofluorescent staining, was measured within the selection using the ImageJ software in an average of 30 neurons/group from three independent experiments. Three sets of experiments were analyzed. One set contained 14 groups of the time course experiments of sst $2 \mathrm{~A}$ receptor recycling (Control without OCT; 15, 30, 45, 60, 120, and $180 \mathrm{~min}$ after OCT washout with or without Ang IV). The second set contained six groups (Control without agonist; $45 \mathrm{~min}$ after OCT washout and $45 \mathrm{~min}$ after SRIF washout with or without Ang IV). The third set contained four groups of the lentiviral shRNA experiments (IRAP LV-shRNA1-3 constructs and NT LV-shRNA control; 45 min after OCT washout). Mean values for the experimental groups were calculated and statistically analyzed.

Binding of IRAP ligands to sst $2 \mathrm{~A}$ receptor in stably transfected $\mathrm{CHO}-\mathrm{K} 1$ cells. Chinese Hamster Ovary (CHO-K1) cells stably transfected with the sst2A receptor were plated in 24-well plates (BD Biosciences) and cultured until confluence in DMEM supplemented with L-glutamine (2 $\mathrm{mm}), 2 \%(\mathrm{v} / \mathrm{v})$ of a stock solution containing $5000 \mathrm{IU} / \mathrm{ml}$ penicillin, and $5000 \mu \mathrm{g} / \mathrm{ml}$ streptomycin (Invitrogen), $1 \%$ (v/v) of a stock solution containing nonessential amino acids, $1 \mathrm{~mm}$ sodium pyruvate, and 10\% (v/v) FBS (Invitrogen). Before the experiment, cells were washed twice with $500 \mu$ l per well of Krebs buffer $\left(20 \mathrm{mM} \mathrm{CaCl}_{2}, 2.7 \mathrm{~mm} \mathrm{KCl}, 2.1 \mathrm{mM} \mathrm{MgCl}_{2}\right.$, $137 \mathrm{~mm} \mathrm{NaCl}$, and $20 \mathrm{~mm}$ HEPES, $\mathrm{pH}$ 7.4) at RT. Incubations were performed for $45 \mathrm{~min}$ at $37^{\circ} \mathrm{C}$ in a final volume of $500 \mu \mathrm{l}$ per well consisting of $400 \mu \mathrm{l} \mathrm{Krebs} \mathrm{buffer,} 50 \mu \mathrm{l}$ of increasing concentrations of Ang IV or LVV-H7 $\left(10^{-9} \mathrm{M}\right.$ to $\left.10^{-5} \mathrm{M}\right)$ and $50 \mu \mathrm{l}^{125} \mathrm{I}$-labeled SRIF (0.5 nM). At the end of the incubation period, the plates were placed on ice and washed three times with ice-cold PBS. For whole-cell binding (i.e., without distinction between surface-binding and intracellular accumulation of the radioligand), cells were then solubilized by addition of $300 \mu \mathrm{l}$ $\mathrm{NaOH}(1 \mathrm{M})$. After 60 min treatment at RT, solutes were transferred in scintillation vials. A total of $3 \mathrm{ml}$ of scintillation liquid (Optiphase Hisafe, PerkinElmer) was added, and the remaining radioactivity was measured in a $\gamma$-counter (PerkinElmer). The experiments were repeated four times, and results are shown in a compilation graph as the percentage of ${ }^{125} \mathrm{I}$-labeled SRIF binding to sst2A receptors, in the presence of Ang IV or LVV-H7.

Focal pilocarpine-induced seizures in rats: surgery. Adult male Wistar rats $(275-300 \mathrm{~g})$ were anesthetized with a mixture of ketamine and diazepam (start dose: 90:4.5 mg/kg), placed on a stereotaxic frame, and implanted with a microdialysis guide cannula (CMA/12, CMA Microdialysis/ $\mathrm{AB})$ above the left (or right) hippocampus at flat skull coordinates: anterior $-5.6 \mathrm{~mm}$, lateral $\pm 4.6 \mathrm{~mm}$, ventral $-4.6 \mathrm{~mm}$ relative to bregma. For experiments with intrahippocampal EEG recording, the guide cannula was customized by gluing an insulated electrode wire to the guide cannula and exposing it over a length of $0.5 \mathrm{~mm}$ beyond the tip 


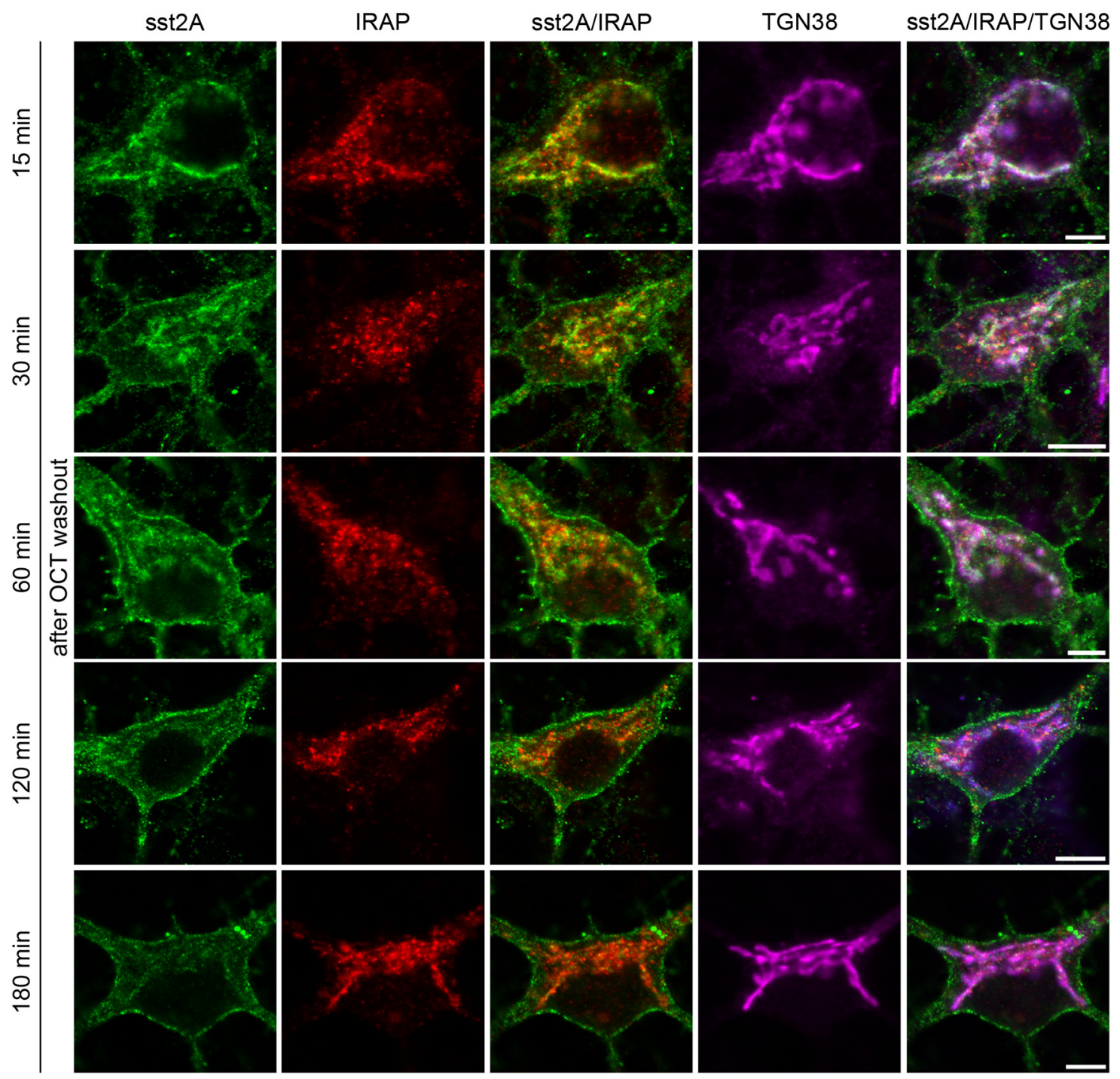

Figure 4. Kinetics of $s$ st2A receptor recycling in primary hippocampal neurons. Fifteen minutes after agonist washout, only intracellular sst $2 \mathrm{~A}$ receptor immunoreactivity is apparent. Thirty minutes after $0 \mathrm{CT}$ washout, the large majority of sst2A receptor immunofluorescence is still intracellular. However, membrane-associated receptors become apparent in perikarya and proximal dendrites. From 60 to 120 min after agonist washout, the surface sst2A receptor labeling becomes more and more intense. In parallel, the intensity of intracellular immunofluorescence gradually decreases. At $180 \mathrm{~min}$ after OCT washout, the distribution of sst2A receptor immunoreactivity is very similar to control conditions (i.e., before agonistinduced internalization of the receptor). The colocalization of sst2A receptor with IRAP (yellow pseudocolor signal on sst2A/IRAP merged images) and TGN38 (white pseudocolor signal on sst2A/IRAP/TGN38 merged images) is important at $30 \mathrm{~min}$ after octreotide washout and gradually decreases from 60 to $180 \mathrm{~min}$. Thirty neurons/group were analyzed from three independent experiments. Scale bars, $10 \mu \mathrm{m}$.

of the guide cannula. The guide was secured to the skull with dental cement. For experiments with intrahippocampal EEG recordings, rats were subcutaneously implanted with a sterilized radiotelemetric transmitter (F20-EET, Data Sciences International), which was then subcutaneously tunneled to the intrahippocampal measuring electrode, and the reference electrode, which was attached to the skull with a stainless steel screw implanted $1 \mathrm{~mm}$ anterior of $\lambda$. Postoperative analgesia was provided by subcutaneous ketoprofen $(3 \mathrm{mg} / \mathrm{kg})$. A concentric microdialysis probe ( $3 \mathrm{~mm}$ length, CMA/12 Elite, CMA Microdialysis/AB) was inserted into the guide cannula. Following transfer of the animals to the microdialysis cage, the microdialysis probe was perfused with a modified Ringer's solution ( $147 \mathrm{~mm} \mathrm{NaCl}, 4 \mathrm{~mm} \mathrm{KCl}, 2.3 \mathrm{~mm} \mathrm{CaCl}_{2}$ ) at a flow rate of $2 \mu \mathrm{l} / \mathrm{min}$ using a CMA infusion pump (CMA120, CMA Microdialysis/ $\mathrm{AB})$. Rats had free access to food and water. Confirmation of unilateral probe placement was established at the end of each experiment on $50 \mu \mathrm{m}$ brain slices prepared on a cryostat (Reichtert-Jung 1206, Cambridge Instruments).

Microdialysis and seizure severity assessment. All microdialysis experiments were performed on the day following surgery. A microdialysis flow rate of $2 \mu \mathrm{l} / \mathrm{min}$ was maintained throughout the pilocarpine experiments. Seizures were evoked by adding $10 \mathrm{~mm}$ pilocarpine to the perfusion liquid during two 20 min sampling periods. Animals were rated on a seizure severity scale based on Racine's scale, which was adopted to include behavioral changes observed in the focal pilocarpine model: 0 , normal nonepileptic activity; 1 , stereotypical mouth and facial movements, wet dog shakes; 2, head nodding, tremor, staring; 3 , forelimb clonus, forelimb extension; 4 , rearing, tonic-clonic activity; and 5, falling (Meurs et al., 2008). The total seizure severity score (TSSS) was the sum of the highest seizure severity score (SSS) observed in each of the seven collection periods following the start of pilocarpine administration and was used as a measure of seizure severity. Additional experiments were performed in rats implanted with an intrahippocampal EEG recording electrode and radiotelemetric transmitter. These rats were placed in a microdialysis bowl equipped with an EEG monitoring unit with radiotelemetric receiver (PhysioTel RPC-1, Data Sciences International) coupled to a Notocord-hem Evolution acquisition system (Notocord). The intrahippocampal EEG was sampled at $100 \mathrm{~Hz}$ during microdialysis sampling and the total EEG seizure duration and latency until the first EEG 

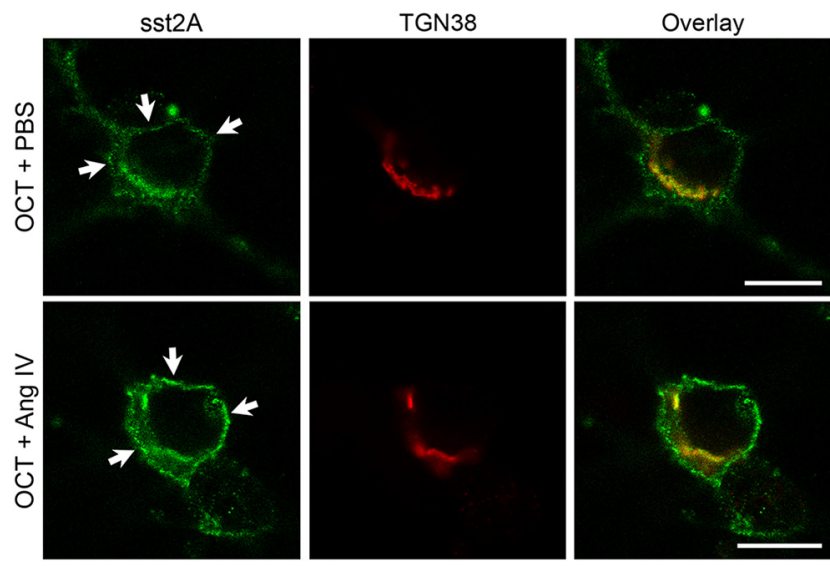

Figure 5. IRAP ligands accelerate sst2A receptor recycling in hippocampal neurons. At 45 min after 0CT washout, sst2A receptor immunoreactivity is localized in the cytoplasm, overlapping with TGN38, as well as at the cell surface in a form of a fluorescent ring (arrows). The surface sst $2 \mathrm{~A}$ receptor labeling is more intense in the Ang IV-treated neuron than in the PBS control. Scale bars, $10 \mu \mathrm{m}$

seizure was determined. The observed behavioral seizures were correlated to EEG seizures by linear regression analysis. Protocols differed between experimental groups as detailed below.

Effect of intrahippocampal Ang IV and LVV-H7 in the focal pilocarpine model. Following the collection of 8 baseline samples 0 , 1, or $10 \mu \mathrm{M}$ Ang IV or LVV-H7 were perfused through the microdialysis probe from the ninth sample collection period onwards. Pilocarpine was coperfused at a concentration of $10 \mathrm{~mm}$ during the 13th and 14th sample collection periods. Hippocampal dialysate samples were subsequently collected for an additional five collection periods.

Involvement of the sst $2 \mathrm{~A}$ receptor in the anticonvulsive effects of Ang IV and $\mathrm{LVV}-\mathrm{H} 7$. The involvement of the sst $2 \mathrm{~A}$ receptor in the observed effects of Ang IV and LVV-H7 was investigated in experiments with collection of six baseline samples, followed by perfusion of the microdialysis probe with $0.1 \mu \mathrm{M}$ cyanamid 154806 (Sigma-Aldrich) or $0.1 \mu \mathrm{M}$ BIM-23627 (kindly provided by Dr. Michael D. Culler, Ipsen Pharma) from the seventh sample collection period onwards. From the ninth sample collection period onwards, 0,10 , and $15 \mu \mathrm{M}$ Ang IV or $10 \mu \mathrm{M}$ LVV-H7 were added to the perfusion liquid. Pilocarpine was coperfused at a concentration of $10 \mathrm{~mm}$ during the 13th and 14th sample collection periods. Hippocampal dialysate samples were collected for an additional five collection periods.

Selectivity of the effects of Ang IV and LVV-H7 in the focal pilocarpine model. The involvement of the AT1 receptor in the observed effects of Ang IV and the involvement of the $\mu / \kappa$ opioid receptors in the anticonvulsant effects of LVV-H7 was investigated in experiments according to exactly the same microdialysis protocol as described above for the sst2A receptors. AT1 receptor antagonist candesartan and $\mu / \kappa$ opioid receptor antagonist naltrexone were used at $0.1 \mu \mathrm{M}$ concentration.

Potentiation of the anticonvulsive effect of SRIF by Ang IV in the focal pilocarpine model. The effect of Ang IV on the anticonvulsive effect of SRIF was further investigated according to the previously described microdialysis protocol. Ang IV and SRIF were used in a subthreshold concentration that did not affect pilocarpine-induced seizures as such. Essentially, we used $1 \mu \mathrm{M}$ for Ang IV and $0.1 \mu \mathrm{M}$ for SRIF. Ang IV and SRIF were perfused through the microdialysis probe, either alone or in combination, from the ninth sample collection period onwards. Pilocarpine was coperfused at a concentration of $10 \mathrm{~mm}$ during the 13th and 14th sample collection periods. Hippocampal dialysate samples were subsequently collected for an additional five collection periods. Two rats treated with the combination of Ang IV and SRIF did not show EEG seizure activity and were excluded for analysis of EEG seizure latency.

Effects of IRAP ligands on rat hippocampal SRIF. Stereotactic surgery for bilateral probe implantation in left and right hippocampus was performed as described above for the unilateral intrahippocampal probe implantation. Microdialysis probes (3 mm length, CMA/12 Elite, CMA Microdialysis/AB) were continuously perfused with aCSF $(125 \mathrm{~mm} \mathrm{NaCl}$, $2.5 \mathrm{~mm} \mathrm{KCl}, 1.2 \mathrm{~mm} \mathrm{CaCl}_{2}, 1.2 \mathrm{mM} \mathrm{MgCl}_{2}, 3.5 \mathrm{~mm} \mathrm{NaH}_{2} \mathrm{PO}_{4}, 0.2 \mathrm{~mm}$ ascorbic acid, $0.025 \% \mathrm{BSA}, \mathrm{pH} 7.4$ ) at a flow rate of $1.0 \mu \mathrm{l} / \mathrm{min}$ using a microdialysis pump (CMA120, CMA Microdialysis/AB) following transfer of the animals to a microdialysis cage with free access to food and water. The day following surgery, samples from the two bilateral probes were collected every $30 \mathrm{~min}$ and pooled, yielding a total volume of $60 \mu \mathrm{l}$. At the beginning of each experiment, samples were collected under baseline conditions, corresponding to perfusion of the probe with aCSF alone. Then $10 \mu \mathrm{M}$ Ang IV or $10 \mu \mathrm{M} \mathrm{LVV-H7} \mathrm{was} \mathrm{added} \mathrm{to} \mathrm{the} \mathrm{perfusion}$ liquid for the remainder of the experiment. SRIF dialysate content was determined using a radioimmunoassay with $\left[{ }^{125} \mathrm{I}\right]-\mathrm{Tyr}^{11}$-somatostatin (IM 161, GE Healthcare) and an SRIF antibody (N 1611, GE Healthcare) raised against cyclic SRIF. A standard curve was prepared using $\left[{ }^{125} \mathrm{I}\right]-$ $\mathrm{Tyr}^{11}$-somatostatin $(6000 \mathrm{cpm}, 2200 \mathrm{Ci} / \mathrm{mmol})$, the antibody (final dilution 1/3000) and synthetic cyclic SRIF in a $0.8 \mathrm{ml}$ solution containing $50 \mathrm{~mm}$ sodium phosphate, $10 \mathrm{~mm}$ EDTA, and $0.3 \% \mathrm{BSA}, \mathrm{pH}$ 7.4. The radioactivity was counted with a $\gamma$-counter. Results were read from the standard curve, and the minimal detectable dose was $39.3 \mathrm{pg} / 100 \mu \mathrm{l}$. Confirmation of bilateral probe placement was again established at the end of each experiment on $50 \mu \mathrm{m}$ brain slices prepared on a cryostat (Reichtert-Jung 1206, Cambridge Instruments).

Electron microscopy. For electron microscopic detection of the sst2A receptor in pilocarpine-treated rats in the presence or absence of Ang IV, a similar microdialysis protocol (described in Effect of intrahippocampal Ang IV and LVV-H7 in the focal pilocarpine model) was used. However, after the 15th collection period (time point where maximal seizures are detected), rats were deeply anesthetized with sodium pentobarbital (60 $\mathrm{mg} / \mathrm{kg}$ i.p.) and perfused through the ascending aorta with $100 \mathrm{ml}$ of saline followed by $400 \mathrm{ml}$ of ice-cold $4 \%$ PFA and $0.05 \%$ glutaraldehyde in $\mathrm{PB}$. Brains were postfixed overnight in $4 \% \mathrm{PFA}$ at $4^{\circ} \mathrm{C}$. Coronal sections were cut on a vibratome at $70 \mu \mathrm{m}$ and collected in PBS. Sections within $1 \mathrm{~mm}$ of the microdialysis probe were selected and equilibrated in $25 \%$ sucrose and $10 \%$ glycerol in $0.05 \mathrm{M} \mathrm{PB}$, frozen rapidly in isopentane cooled in liquid nitrogen, and thawed in PBS at RT.

For preembedding immunocytochemistry, sections were preincubated for $30 \mathrm{~min}$ in 5\% NGS in PBS. Sections were then incubated overnight at RT in rabbit anti-sst2A receptor antibody (1:1000) diluted in PBS containing $1 \%$ NGS. After washing in PBS, sections were incubated for $120 \mathrm{~min}$ in Nanogold-conjugated goat anti-rabbit IgG (1:100; Nanoprobes) diluted in PBS containing $2 \%$ of BSA-c and $0.2 \%$ of cold water fish gelatin. Sections were washed in PBS and postfixed in $1 \%$ glutaraldehyde in PBS for $10 \mathrm{~min}$. After washings in PBS and $0.1 \mathrm{M}$ sodium acetate buffer, $\mathrm{pH} 7.0$, sst $2 \mathrm{~A}$ receptor immunogold labeling was intensified using a silver enhancement kit (HQ Silver; Nanoprobes) for 5-10 min in the dark at RT. After washings in acetate buffer and in PB, sections were postfixed in $1 \%$ osmium tetroxide in $\mathrm{PB}$ for $10 \mathrm{~min}$ at RT. After washings in PB, they were dehydrated in an ascending series of ethanol, which included $1 \%$ uranyl acetate in $70 \%$ ethanol. They were then treated with propylene oxide twice for $10 \mathrm{~min}$, equilibrated overnight in Durcupan ACM (Fluka), mounted on glass slides, and cured at $60^{\circ} \mathrm{C}$ for $48 \mathrm{~h}$. Areas of interest were cut out from the slide and glued to blank cylinders of resin. Blocks were cut in semithin sections $(1 \mu \mathrm{m})$ and then in ultrathin sections on a Reichert Ultracut $S$ microtome. Ultrathin sections were collected on pioloform-coated single-slot grids. Sections were stained with lead citrate and examined with a Philips CM120 electron microscope equipped with Morada Soft Imaging System (Olympus Soft Imaging Solutions). On the ultrathin sections, only areas at the surface of the vibratome sections were analyzed. The acquired images were equally adjusted for brightness and contrast, and composite illustrations were built in Adobe Photoshop CS3 (Adobe Systems).

Quantification of electron microscopic immunocytochemistry. The subcellular distribution of sst $2 \mathrm{~A}$ receptor in CA1 pyramidal cell dendrites was analyzed using the Measure command and Cell counter plugin of Image J in 3 control and $3 \mathrm{Ang}$ IV-treated rats. An average of 10 dendrites per animal was analyzed. The length of the plasma membrane and the caliber of dendrites (expressed in cross-sectional surface; $\mu \mathrm{m}^{2}$ ) were measured. The sst $2 \mathrm{~A}$ receptor immunoparticles were identified and 
counted in association with the plasma membrane and in the intracellular compartment. Results were expressed as follows: (1) the percentage of immunoparticles associated with the plasma membrane and the intracellular compartment (\%); and (2) density of immunoparticles per membrane length $(\mu \mathrm{m})$ or cytoplasmic surface $\left(\mu \mathrm{m}^{2}\right)$.

Data analysis. Statistical analysis was performed using GraphPad Prism 4.0 (GraphPad). Statistical tests applied to the data are indicated in the figure legends. Differences were considered to be significant at $p<0.05$. All data in text and figures are presented as mean \pm SEM.

\section{Results}

sst2A receptor-expressing neuronal cells colocalize with IRAP in the rat hippocampal formation

The sst2A receptor and IRAP display similar regional expression patterns (Fig. $1 a, c)$. Whereas IRAP imunoreactivity was localized in the principal cells of CA1-3 and dentate gyrus (Fig. $1 c, d$ ), sst2A receptor immunoreactivity is distributed in both dendritic fields and principal cells of the hippocampus (Fig. 1a,d, inset) (Csaba et al., 2001, 2007). In vivo internalization of the receptor through intrahippocampal OCT injections revealed sst $2 \mathrm{~A}$ receptorexpressing cell bodies (Fig. $1 b, e$ ), as previously reported (Csaba et al., 2001, 2007). Double-labeling experiments demonstrated that all hippocampal sst2A receptor-positive neurons displayed IRAP immunoreactivity (Fig. $1 e-g$ ).

\section{Internalized sst $2 \mathrm{~A}$ receptors are targeted to IRAP-positive vesicles in neurons}

IRAP and sst2A receptor subcellular distribution was then studied in cultured rat hippocampal neurons to analyze whether both proteins could colocalize during receptor internalization and recycling. In nontreated control cells (Fig. 2), a predominant plasma membrane distribution of the endogenous sst $2 \mathrm{~A}$ receptor was detected at the surface of perikarya and dendrites, confirming our former results (Csaba et al., 2001, 2007; Lelouvier et al., 2008). In accordance with earlier studies (Fernando et al., 2005, 2007), endogenous IRAP immunoreactivity was mainly confined to intracytoplasmic granules in the perikarya and was also detected in proximal dendrites (Fig. 2). Finally, in the neuronal cell body, IRAP-positive vesicles were located in a perinuclear compartment and overlapped with TGN38, as previously reported (Fernando et al., 2007, 2008) (Fig. 2). In agreement with these latter studies, a faint IRAP signal was also apparent at the plasma membrane. Therefore, little colocalization between sst $2 \mathrm{~A}$ receptor and IRAP was observed in control conditions.

After 5-10 min of agonist stimulation with $1 \mu \mathrm{M}$ OCT, endogenous sst2A receptors were no longer present at the cell surface,
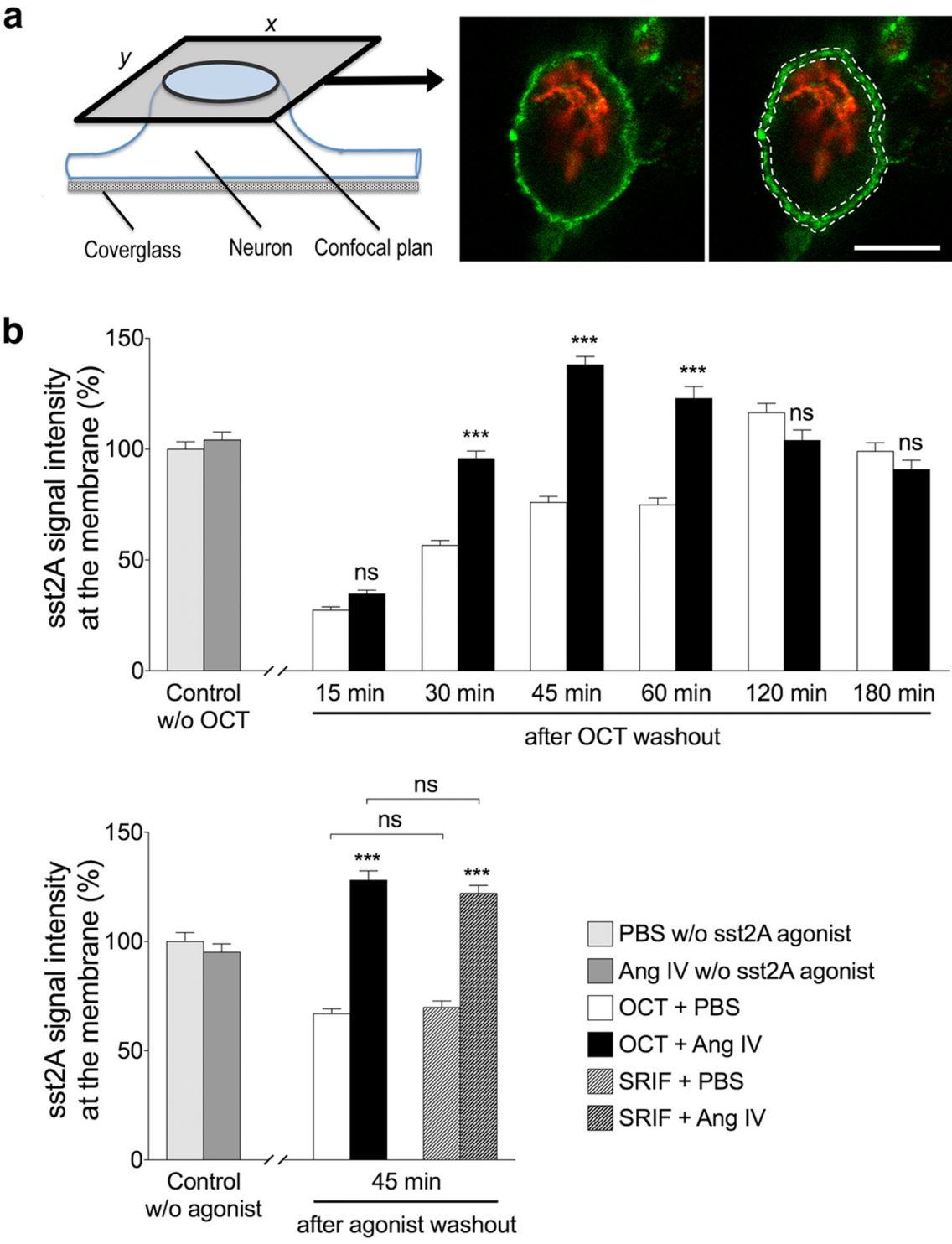

Figure 6. Analysis of sst2A receptor recycling in hippocampal neurons. $\boldsymbol{a}$, For semiquantitative analysis, a single optical section is acquired from the neuronal cell body at a $z$-axis level where the sst2A receptor labeling at the plasma membrane is identified as a line-like ring in the green channel around the TGN38 labeling of the red channel. Scale bar, $10 \mu \mathrm{m}$. $\boldsymbol{b}$, Semiquantitative analysis membrane $45 \mathrm{~min}$ after OCT or SRIF washout in the Ang IV-treated group compared with the respective PBS controls. No icant difference is detected between respective OCT- and SRIF-treated groups (bottom). Thirty neurons/group were analyzed from three independent experiments. Values are expressed in relation to an arbitrary unit (100\%) of the control value (PBS without agonist). ${ }^{* * *} p<0.001$ (ANOVA followed by Bonferroni's multiple comparison test). ns, Not significant.

and bright fluorescent accumulations appeared in the cytoplasm of perikarya and dendrites (Fig. 2). The same redistribution of sst2A immunoreactivity was observed after $1 \mu \mathrm{M}$ SRIF treatment (data not shown), as previously reported (Lelouvier et al., 2008). Very interestingly, extensive colocalization between sst2A receptor and IRAP immunoreactivity was detected both in perikarya and proximal dendrites between 5 and 20 min following the beginning of the OCT treatment, as shown by the yellow pseudocolor signal present in the overlaid images (Figs. 2, 3). This indicates that internalized receptors are massively targeted to IRAP-positive intracellular compartments in hippocampal neurons. This colocalization gradually decreased in time as the receptor recycled back to the plasma membrane (Fig. 4). 
a

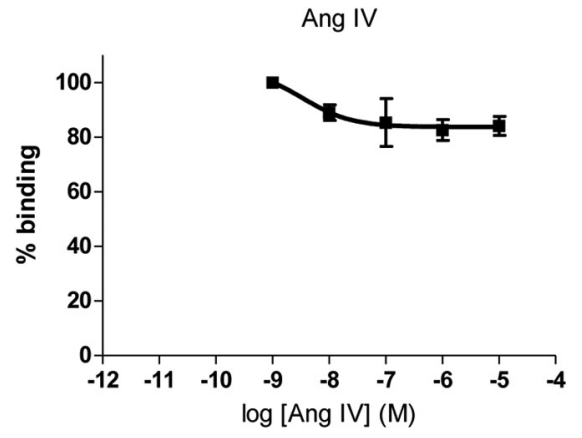

b

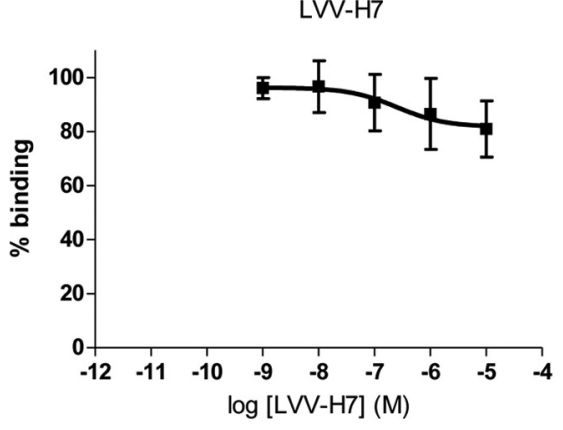

Figure 7. IRAP ligands do not bind to the sst2A receptor in stably transfected CHO-K1 cells. The specific binding of Ang IV (a) and LVV-H7 (b) to sst2A receptors in CH0-K1 cells was investigated by incubating these cells with increasing concentrations $\left(10^{-9} \mathrm{M}\right.$ to $10^{-5} \mathrm{M}$ ) of IRAP ligands and $0.5 \mathrm{~nm}$ radiolabeled SRIF. In four independent experiments, the ${ }^{125} \mathrm{I}$-labeled SRIF and IRAP ligands competed for binding to sst2A receptors, after which the number of counts per minute was measured. The results are shown as the percentage of ${ }^{125}$ I-labeled SRIF binding to sst2A receptors.

\section{IRAP ligand accelerates sst2A receptor recycling in hippocampal neurons}

Next, we performed kinetic experiments to analyze whether IRAP ligand Ang IV could impact on the trafficking and recycling of endogenous sst2A receptor following agonist-induced internalization (Fig. 5). In hippocampal neurons treated with OCT but in the absence of Ang IV, reappearance of sst $2 \mathrm{~A}$ receptors at the plasma membrane of the cell body was first evident $30 \mathrm{~min}$ after OCT washout. Three hours after OCT stimulation, receptor distribution and density were similar to control conditions (i.e., receptors were localized at the plasma membrane of both the cell body and dendrites).

In hippocampal neurons treated with OCT but in the presence of Ang IV, we observed a shift of the reappearance of the sst $2 \mathrm{~A}$ receptors at the plasma membrane (Figs. 5, 6). At 30, 45, and 60 min after OCT washout, the amount of membrane-associated receptors was significantly higher in Ang IV-treated neurons $(\mathrm{OCT}+$ Ang IV) than in respective controls (OCT + PBS) (30 min: $+69 \%$; 45 min: $+82 \%$; 60 min: $+64 \%$; Fig. 6b). No difference was observed in the recycling kinetics of the sst $2 \mathrm{~A}$ receptor following SRIF- or OCT-induced internalization. Notably, Ang IV treatment resulted in a faster sst $2 \mathrm{~A}$ receptor recycling with both agonists (Fig. 6b). Interestingly, within the Ang IV-treated group, we observed that, 45 and $60 \mathrm{~min}$ after OCT washout, the density of receptors at the plasma membrane was significantly higher than in cells not treated with OCT (Ang IV without OCT) (45 min: $+33 \%, p<0.001 ; 60$ min: $+18 \%, p<0.01$; Dunnett's multiple comparison test; Fig. $6 b$ ). In cells treated with OCT in the absence of Ang IV, this phenomenon was also apparent but only $120 \mathrm{~min}$ after OCT washout $(+16 \%$ vs PBS without OCT, $p<0.001$, Dunnett's multiple comparison test; Fig. 6b). These data suggest that massive pools of sst $2 \mathrm{~A}$ receptors are first targeted from the perinuclear recycling compartment to the plasma membrane of the cell body, before diffusing to the dendritic fields along the membranes, and this process is accelerated in Ang IV-treated neurons. Together, these results suggest that the IRAP ligand has shortened the recycling time of internalized sst $2 \mathrm{~A}$ receptors to the plasma membrane.

\section{IRAP ligands do not bind the sst $2 \mathrm{~A}$ receptor}

To analyze whether the Ang IV effects on sst2A receptor recycling could be due to putative cross-reaction between the IRAP ligands and the sst $2 \mathrm{~A}$ receptor, cultured hippocampal neurons were treated with $1 \mu \mathrm{M}$ Ang IV or LVV-H7 and fixed 20-180 min thereafter for immunoreactive detection of the endogenous sst2A receptor. Neither Ang IV nor LVV-H7 did change the distribution of sst $2 \mathrm{~A}$ receptor immunoreactivity (data not shown). The possible direct interaction between IRAP ligands and the sst2A receptor was also investigated in CHO-K1 cells stably transfected with the sst $2 \mathrm{~A}$ receptor incubated with increasing concentrations of Ang IV and LVV-H7. The total percentage of ${ }^{125} \mathrm{I}-$ labeled SRIF binding to sst $2 \mathrm{~A}$ receptor $\mathrm{did}$ not change throughout the whole experiment, in the presence of either Ang IV or LVV-H7 (Fig. 7). Together, these results indicate that direct interactions between IRAP ligands and sst $2 \mathrm{~A}$ receptors are unlikely.

\section{IRAP knockdown also accelerates sst $2 \mathrm{~A}$ receptor recycling in hippocampal neurons}

To confirm the specificity of IRAP effects on sst2A receptor trafficking, we next aimed to silence IRAP expression in hippocampal neurons through lentiviral-mediated RNA interference. The protein expression level of IRAP was analyzed by semiquantitative laser scanning confocal microscopy in individual transduced neurons (Fig. $8 a, b$ ). Data revealed a significant inhibition of IRAP expression by three separate IRAP-targeting shRNAs compared with control shRNA (IRAP LV-shRNA1: - 76\%; IRAP LVshRNA2: $-70 \%$; IRAP shRNA3: $-60 \%$; Fig. $8 b$ ). This selective downregulation of IRAP had no effect on the targeting of the sst $2 \mathrm{~A}$ receptor to the plasma membrane or on the capacity of the receptor to internalize after OCT stimulation. Importantly, when we analyzed the recycling of the receptor at the time point $45 \mathrm{~min}$ after OCT washout (Fig. 9a,b; chosen on the basis of pharmacological experiments for which the difference between Ang IVtreated and respective control neurons was the highest), we found that the density of the receptor at the plasma membrane was significantly higher in neurons transduced with IRAP-targeting shRNAs than in neurons transduced with control shRNA (IRAP LV-shRNA1: + 56\%; IRAP LV-shRNA2: + 62\%; IRAP shRNA3: $+53 \%$; Fig. 9b). These results suggest that reduction of IRAP expression has shortened the time of recycling of internalized receptors to the plasma membrane and that IRAP is therefore a negative regulator of sst $2 \mathrm{~A}$ receptor recycling.

\section{Intrahippocampal Ang IV or LVV-H7 administration is anticonvulsive in the rat focal pilocarpine model}

To further analyze whether a faster recovery of internalized sst $2 \mathrm{~A}$ receptors at the plasma membrane in response to IRAP ligands could be relevant in vivo, we next studied the effects of intrahippocampal administration of Ang IV and LVV-H7 in a rat model of focal seizures. Indeed, an increase in SRIF immunoreactivity and secretion is known to occur in epileptic hippocampal tissues (Tallent and Qiu, 2008), and several studies argue for a concomitant internalization of the sst2A receptors (Csaba et al., 2004, 2005).

Intrahippocampal perfusion of $10 \mathrm{~mm}$ pilocarpine via a microdialysis probe induced a range of behavioral changes, including wet dog shakes, typically beginning within $20 \mathrm{~min}$ following the start of pilocarpine administration. These changes progressively evolved into bouts of staring, stereotypical mouth and facial movements, forelimb clonus, and rearing. The behavioral 
a

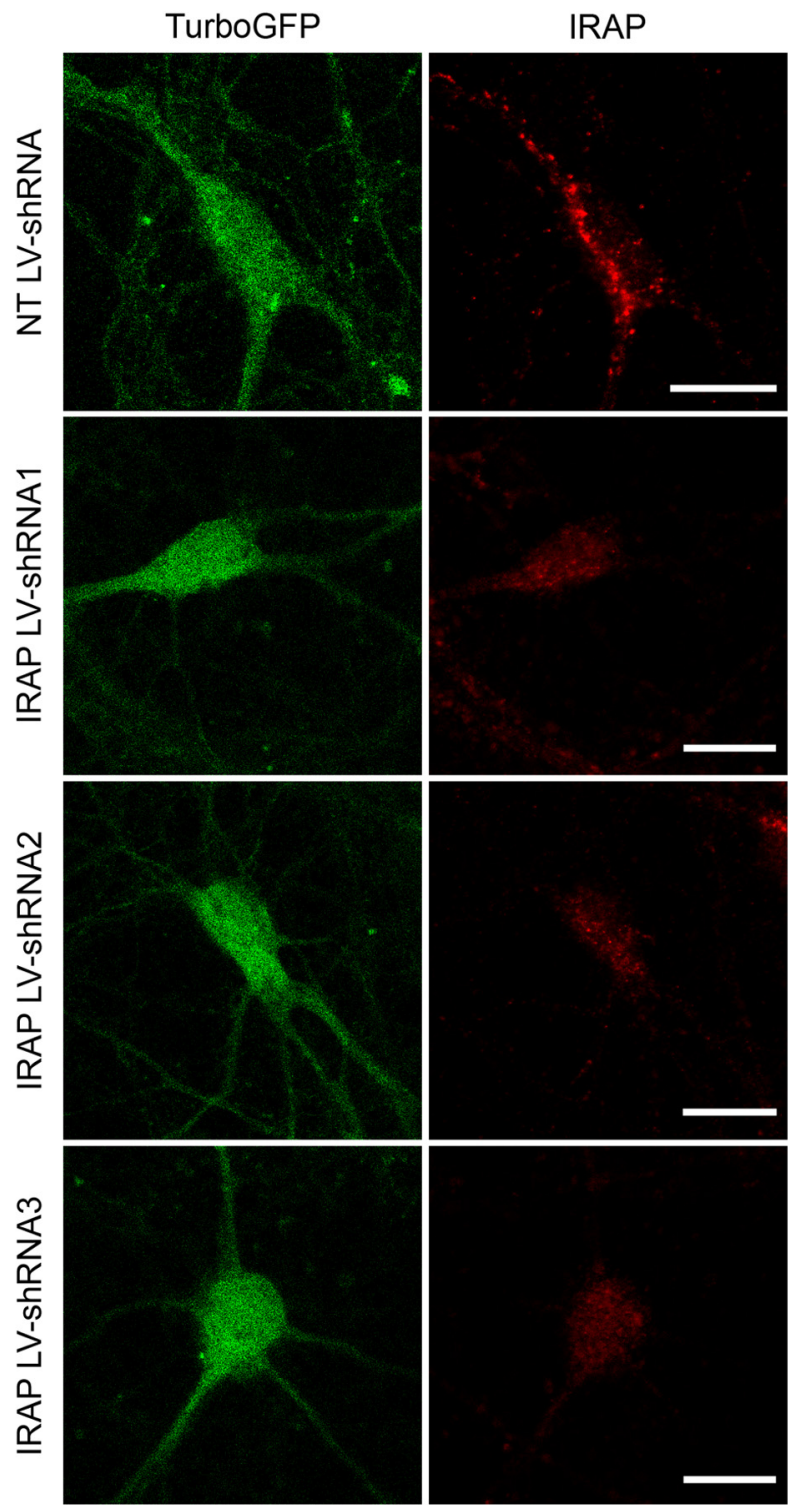

b

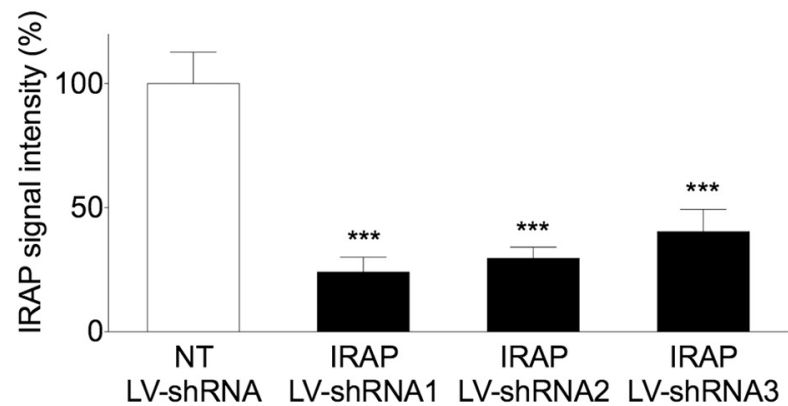

Figure 8. IRAP-targeting shRNAs decreases IRAP immunoreactivity in hippocampal neurons. $\boldsymbol{a}$, Using TurboGFP lentiviral particles with three IRAP-targeting shRNAs (IRAP LVshRNA1-3) and a nontargeting control (NT LV-shRNA), neuronal transduction is demonstrated by the presence of the TurboGFP signal (green). In neurons transduced with nontargeting LV-shRNA, IRAP immunoreactivity is mainly confined to vesicles in the cell bodies and proximal dendrites (red). In neurons transduced with IRAP-targeting shRNA, the intensity of IRAP immunofluorescence is low. Scale bars, $10 \mu \mathrm{m}$. $\boldsymbol{b}$, Semiquantitative analysis reveals that the intensity of IRAP immunoreactivity in the IRAP LV-shRNA1-3 groups is significantly lower compared with the NT LV-shRNA controls. Thirty neurons/group were analyzed from three independent experiments. ${ }^{* *} p<0.001$ (ANOVA followed by Bonferroni's multiple comparison test). changes correlated with electrocorticographic seizures, as previously demonstrated (Meurs et al., 2008). Pilocarpine-treated animals received intrahippocampal coperfusions of 1 or $10 \mu \mathrm{M}$ of the IRAP ligands Ang IV or LVV-H7 through a microdialysis probe. The maximum SSS (Fig. $10 a, b$; Bin 12) of animals perfused with $1 \mu \mathrm{M}$ Ang IV or $1 \mu \mathrm{M}$ LVV-H7 was not significantly different from the maximum SSS of animals in the pilocarpine control group. Similarly, the mean TSSSs of animals treated with $1 \mu \mathrm{M}$ Ang IV or $1 \mu \mathrm{M}$ LVV-H7 were not significantly different from the mean TSSSs observed in the pilocarpine control group. By contrast, the maximum SSSs (Fig. 10a,b; Bin 12) for animals treated with $10 \mu \mathrm{M}$ Ang IV or $10 \mu \mathrm{M}$ LVV-H7 were significantly lower compared with the SSSs in animals of the pilocarpine control group (Fig. 10a,b). In animals treated with $10 \mu \mathrm{M}$ Ang IV or $10 \mu \mathrm{M}$ LVV-H7, only minor seizure-related behavioral changes were observed, such as wet dog shakes and less commonly staring. Correspondingly, the mean TSSSs of animals treated with $10 \mu \mathrm{M}$ Ang IV or $10 \mu \mathrm{M}$ LVV-H7 were significantly lower compared with the mean TSSSs observed in the pilocarpine control group (Fig. $10 a, b$ ). Together, these results demonstrate that IRAP ligands, at a microdialysis probe perfusion concentration of $10 \mu \mathrm{M}$, display anticonvulsant effects.

\section{The anticonvulsant effects of IRAP ligands are mediated by the sst $2 \mathrm{~A}$ receptor}

To further analyze whether the anticonvulsant properties of IRAP could be mediated by the sst $2 \mathrm{~A}$ receptor, we next studied the effect of intrahippocampal coadministration of sst2A receptor antagonists and IRAP ligands in the same limbic seizure model. The sst2A receptor antagonists cyanamid 154806 or BIM23627 did not significantly affect seizure severity compared with the pilocarpine control groups when perfused in the hippocampus at a concentration of $0.1 \mu \mathrm{M}$ (Fig. 11a,b). However, seizure severity was significantly higher in animals perfused with $0.1 \mu \mathrm{M}$ cyanamid 154806 followed by $10 \mu \mathrm{M}$ Ang IV (Fig. 11a) or $10 \mu \mathrm{M}$ LVV-H7 (Fig. 11c) and $0.1 \mu \mathrm{M}$ BIM-23627 followed by 15 $\mu \mathrm{M}$ Ang IV (Fig. 11b) compared with Ang IV and LVV-H7 alone (Fig. $11 a-c)$. Together, these experiments demonstrate that sst2A receptor antagonists abolish the anticonvulsant effects of Ang IV and LVV-H7 and that the sst2A receptor is thus a key factor for the anticonvulsant effects mediated by the IRAP ligands.

The anticonvulsant effects of IRAP ligands are independent of angiotensin AT1 and $\boldsymbol{\mu} / \boldsymbol{\kappa}$ opioid receptor activation

Because Ang IV and LVV-H7 were previously characterized as low-affinity angiotensin AT1 (Yang et al., 2008; De Bundel et al., 2009,2010 ) and opioid $\mu / \kappa$ receptor (Zhao et al., 1997; Lee et al., 2001) agonists, we therefore investigated the possible involvement of these receptor subtypes in the anticonvulsant effects of Ang IV and LVV-H7. The angiotensin AT1 receptor antagonist candesartan and the opioid $\mu / \kappa$ receptor antagonist naltrexone, perfused into the hippocampus at a concentration of $0.1 \mu \mathrm{M}$, had no significant effect on seizure severity compared with the pilocarpine control group (Fig. 12a,b). Furthermore, pretreatment with candesartan or naltrexone did not abolish the anticonvulsive effect of Ang IV and LVV-H7 compared with the pilocarpine control group (Fig. 12a,b).

\section{IRAP ligands have no effect on extracellular hippocampal SRIF levels}

Anticonvulsant effects of IRAP ligands could be due, in addition to their effects on sst2A receptor recycling, to an increase in hippocampal SRIF concentrations through inhibition of its degrada- 
a

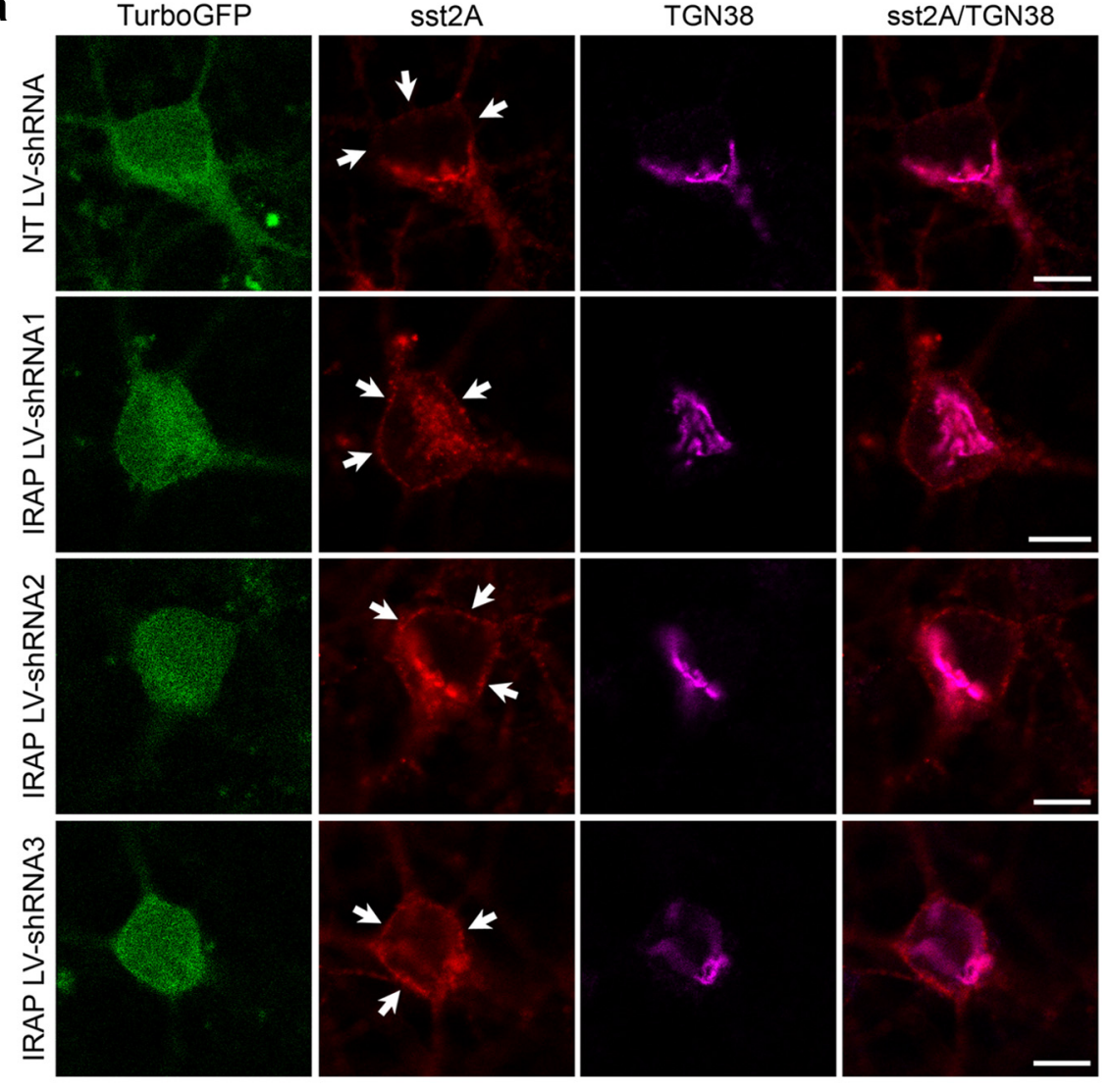

b

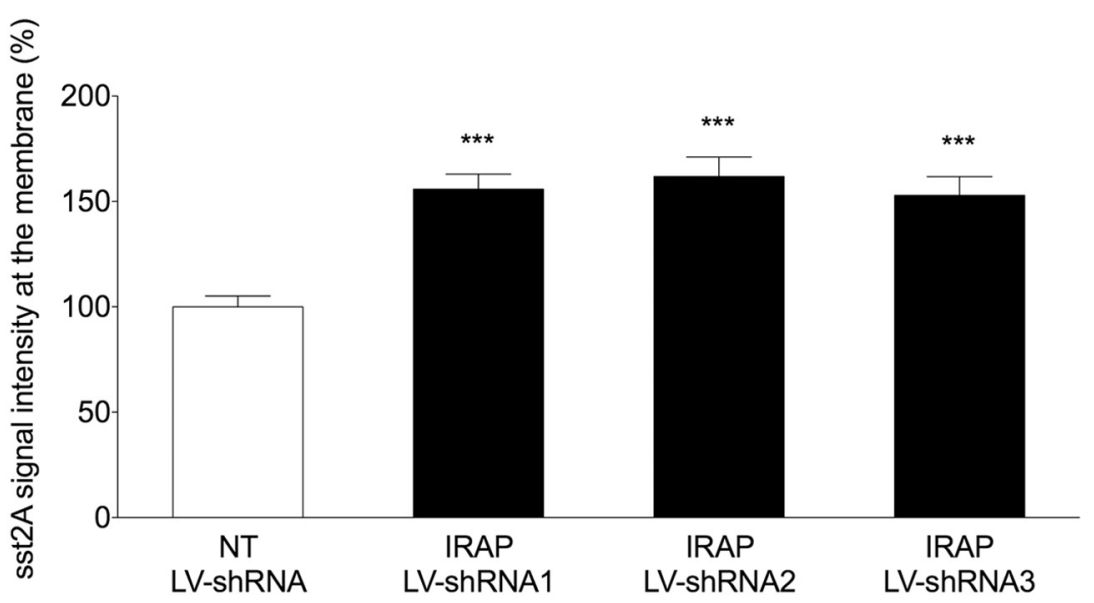

Figure 9. IRAP knockdown increases sst2A receptor recycling in hippocampal neurons. $\boldsymbol{a}$, Using TurboGFP lentiviral particles with three IRAP-targeting shRNAs (IRAP LV-shRNA1-3) and a nontargeting control (NT LV-shRNA), neuronal transduction is demonstrated by the presence of the TurboGFP signal. At 45 min after agonist washout, in neurons transduced with both nontargeting and IRAP-targeting shRNA, the sst2A receptor immunoreactivity is localized in the cytoplasm, overlapping with TGN38. Receptors are also localized at the cell surface (arrows). However, the intensity of the surface sst2A receptor labeling is higher in neurons transduced with IRAP LV-shRNAs than those with the NT LV-shRNA control. Scale bars, $10 \mu \mathrm{m}$. $\boldsymbol{b}$, Semiquantitative analysis reveals that the intensity of sst2A receptor immunoreactivity at the plasma membrane $45 \mathrm{~min}$ after OCT washout is significantly higher in the IRAP LV-shRNA1-3 groups compared with the NT LV-shRNA control. Thirty neurons/group were analyzed from three independent experiments. Values are expressed in relation to an arbitrary unit (100\%) of the control value (NT LV-shRNA). ${ }^{* * *} p<0.001$ (ANOVA followed by Bonferroni's multiple comparison test).

tion, as reported in one in vitro study in PC12 cells (Matsumoto et al., 2001). We therefore analyzed the effects of intrahippocampal administration of anticonvulsant concentrations of Ang IV or LVV-H7 on hippocampal SRIF levels. The mean baseline concentration of SRIF in hippocampal microdialysates was $0.80 \pm$ $0.15 \mathrm{~nm}$. Intrahippocampal perfusion of $10 \mu \mathrm{M}$ Ang IV or $10 \mu \mathrm{M}$
LVV-H7 had no effect on baseline SRIF levels of the hippocampal microdialysates (Fig. 13). The inhibition of enzymatic SRIF degradation is therefore not implicated in the mechanism of anticonvulsant action of the IRAP ligands.

\section{Ang IV potentiates the anticonvulsive effect of SRIF}

We next investigated whether intrahippocampal administration of the IRAP ligand Ang IV could potentiate the anticonvulsive effect of SRIF (Aourz et al., 2011). We found that $1 \mu \mathrm{M}$ Ang IV and 0.1 $\mu \mathrm{M}$ SRIF had no effect on pilocarpineinduced seizures. Coperfusion of both peptides in the same concentration suppressed behavioral seizures (Fig. 14a) and EEG seizures (Fig. 14b-g). These data clearly demonstrate that Ang IV potentiates the anticonvulsive effect of SRIF in the focal pilocarpine model, potentially by increasing the availability of sst $2 \mathrm{~A}$ receptors at the membrane of hippocampal neurons.

\section{IRAP ligands increase the density of membrane-associated sst $2 \mathrm{~A}$ receptors in vivo following evocation of a limbic seizure event}

To further demonstrate that Ang IV antiepileptic effects are driven by an increase of membrane-associated receptors in vivo, as demonstrated in vitro, the density of sst $2 \mathrm{~A}$ receptors was quantified by immunogold electron microscopy in CA1 pyramidal cell dendrites of pilocarpineinjected animals treated or not with an anticonvulsive dose of Ang IV (Fig. 15a-d). Whereas in the pilocarpine control group, $70 \%$ of immunoparticles were found in intracellular compartments and 30\% membrane-associated (Fig. 15a,c), in the animals receiving intrahippocampal perfusion of Ang IV and pilocarpine, the distribution was reversed: $30 \%$ of immunoparticles were intracellular and 70\% membrane-associated (Fig. 15b,c). The latter distribution is close to that we have previously reported in naive animals (i.e., $20 \%$ intracellular and 80\% membraneassociated) (Csaba et al., 2007). Quantitative analysis revealed that the density of sst $2 \mathrm{~A}$ receptors at the plasma membrane was significantly higher in Ang IV-treated animals compared with controls (Fig. 15d). Conversely, the density of intracellular sst2A receptor immunoparticles was significantly lower in Ang IV-treated animals compared with controls (Fig. 15d). These results suggest that, as demonstrated in vitro, Ang IV accelerates the recycling of internalized receptors induced by SRIF release during the evoked seizure process. Together with the fact that sst $2 \mathrm{~A}$ receptor antagonists prevent the anticonvulsive effects me- 
diated by Ang IV or LVV-H7, the recovery of the sst2A receptors at the plasma membrane appears as the key mechanism involved in the anticonvulsive effects mediated by IRAP ligands.

\section{Discussion}

The life cycle of GPCRs includes biosynthesis in the endoplasmic reticulum, maturation in the Golgi, and transport to the cell surface followed by signal transduction at the plasma membrane and often internalization. Additional signaling can also occur in early endosomes as recently demonstrated (Irannejad et al., 2013). GPCR-interacting proteins have been demonstrated to play a critical role along these different phases (von Zastrow and Williams, 2012). However, much remains to be learned about mechanisms that regulate postendocytic sorting and recycling of GPCRs. As documented in our study, the insulin-regulated aminopeptidase, IRAP, appears as a new modulator of GPCR trafficking by affecting the kinetics of the sst $2 \mathrm{~A}$ receptor recycling after ligand activation in neurons. Trans-modulation of the recycling of a GPCR through ligand binding to a non-GPCR membrane protein, has, to our knowledge, not yet been described. Trans-effects on GPCR trafficking were until now only described through oligomerization of receptors (von Zastrow and Williams, 2012), which mostly affect the endocytosis process. Importantly, our study also demonstrates that modulating the recycling of a particular receptor can indeed impact its physiological fate and therefore present a potential therapeutic value.

Within the hippocampus, the major SRIF receptor subtype, the sst2A receptor, is localized at postsynaptic sites of the principal cells (Dournaud et al., 1996; Schindler et al., 1997; Csaba et al., 2007). Although this receptor appears to be an attractive therapeutic target in epilepsy, it rapidly internalizes in vivo before a slow recycling process (Csaba et al., 2007; Lelouvier et al., 2008). This long route has been suggested to have an impact on sst2A receptor-mediated signaling when, in pathophysiological conditions such as epilepsy, a high and chronic release of SRIF occurs (Vezzani and Hoyer, 1999). Indeed, a decreased density of this receptor subtype has been demonstrated in both rat and human epileptic dentate gyrus (Csaba et al., 2004, 2005). Importantly, our present data suggest that downregulation of the sst $2 \mathrm{~A}$ receptor can be counteracted and consequently can increase endogenous SRIF anticonvulsant properties. We first found that internalized receptors travel massively through an intracytoplasmic pool of IRAP-positive vesicles. IRAP has been proposed to serve as a cargo of cell-specific storage vesicles and as an active player in their trafficking (Saveanu and van Endert, 2012). Our findings support this notion because we demonstrate here that IRAP regulates either directly or indirectly the sorting of sst $2 \mathrm{~A}$ receptors from cytoplasmic vesicles to the plasma mem-

a
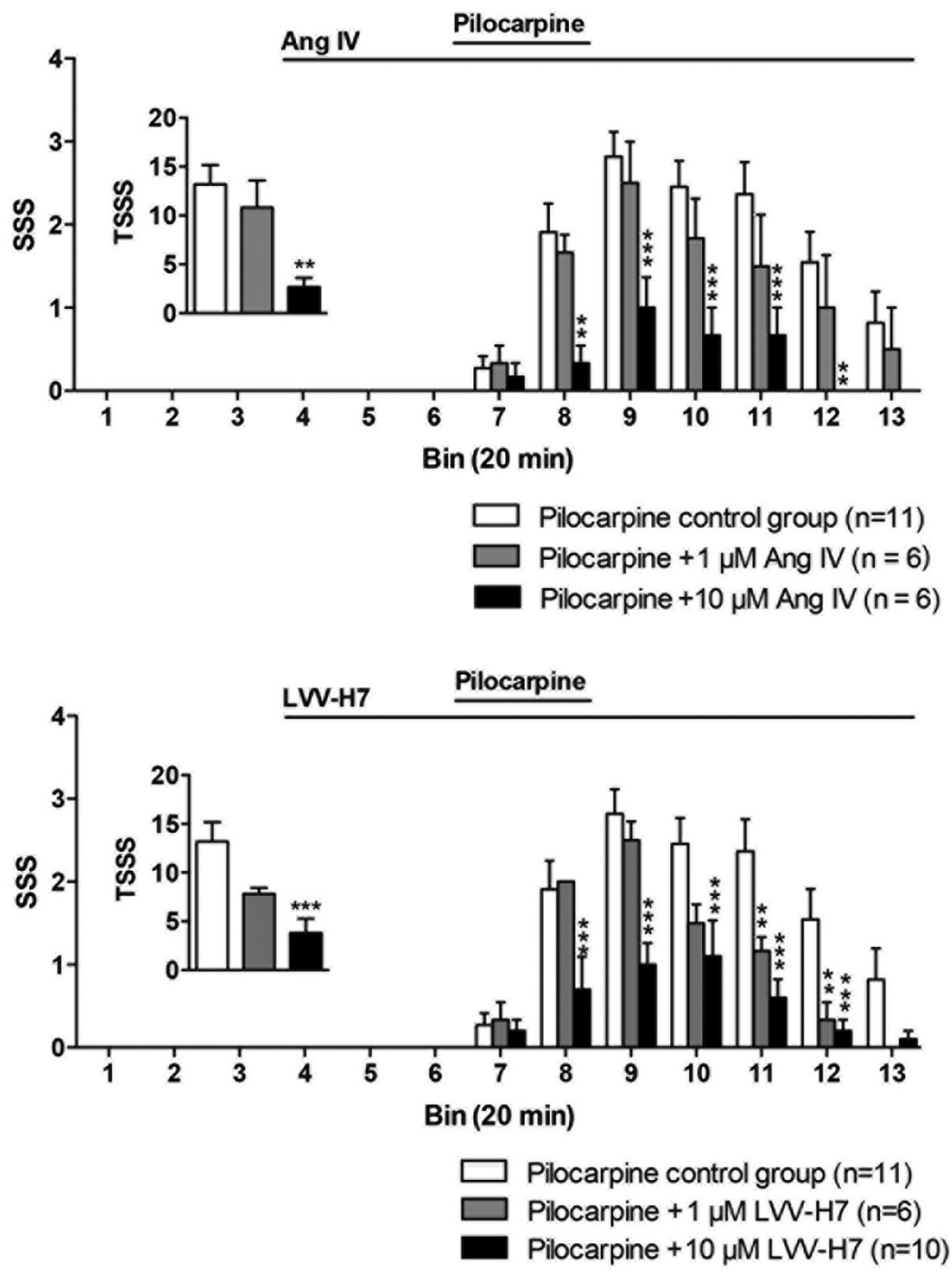

Figure 10. IRAP ligands display anticonvulsive properties in the rat focal pilocarpine model. Time profiles of SSSs are shown with TSSSs in the insets. Both Ang IV (a) and LVV-H7 (b) treatments at $10 \mu \mathrm{m}$ concentration result in a significantly lower SSS and TSSS. ${ }^{* *} p<0.01$ versus pilocarpine control group. ${ }^{* *} p<0.001$ versus pilocarpine control group. SSS: two-way ANOVA followed by Dunnett's multiple comparison test; TSSS: ANOVA followed by Bonferroni's multiple comparison test.

brane. Second, we established that the IRAP ligand Ang IV or the knockdown of IRAP expression both accelerate the recycling of sst2A receptors after their endocytosis in hippocampal cells. These observations suggest a possible trans-modulation of sst2A receptor trafficking by IRAP. We then showed that the anticonvulsive effects of both Ang IV and the structurally distinct peptidergic IRAP ligand LVV-H7 were reversed by intrahippocampal coadministration of two structurally different sst $2 \mathrm{~A}$ receptor antagonists: cyanamid 154806 and BIM-23627. These results unequivocally confirm the involvement of the sst $2 \mathrm{~A}$ receptor in the anticonvulsive effects of the IRAP ligands. Moreover, we found that a low dose of Ang IV, which does not exert anticonvulsive effects as such, potentiates the anticonvulsive action of SRIF. We then asked whether Ang IV and LVV-H7 may exert their anticonvulsive effects through putative inhibition of SRIF degradation via IRAP (Matsumoto et al., 2001). We have established that perfusion of anticonvulsive concentrations of Ang IV or LVV-H7 into the hippocampus had no effect on local SRIF levels. This suggests that IRAP is not involved in SRIF degradation in the rodent brain. Other enzymes, such as endopeptidase-24.11 
a

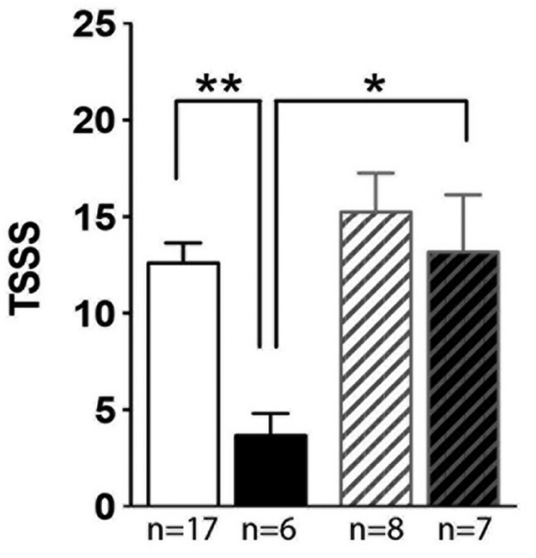

$\begin{array}{rcccc}\text { Pilocarpine } & + & + & + & + \\ \text { Ang IV }(10 \mu \mathrm{M}) & - & + & - & + \\ \text { Cyanamid }(0.1 \mu \mathrm{M}) & - & - & + & +\end{array}$

b

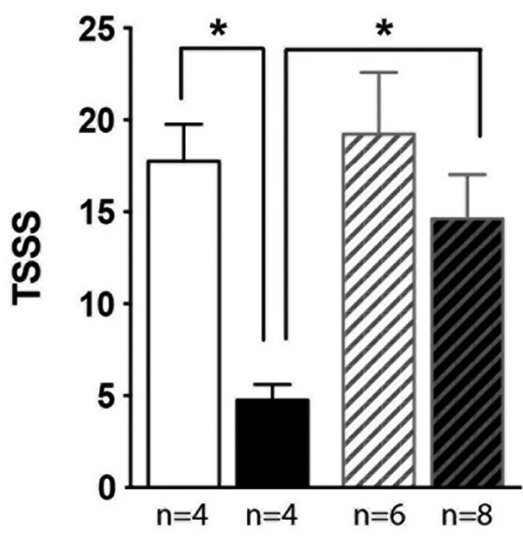

C

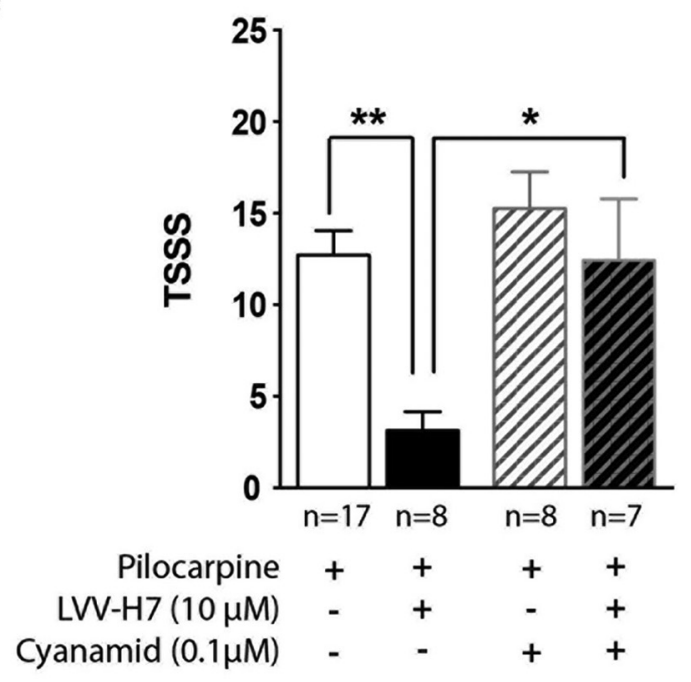

Figure 11. Antagonists of the sst2A receptor prevent the anticonvulsive effect of Ang IV and LVV-H7 in the rat focal pilocarpine model. The sst2A receptor antagonist cyanamid $154806(\boldsymbol{a}, \boldsymbol{c})$ or BIM-23627 (b) reverse the effect of Ang IV $(\boldsymbol{a}, \boldsymbol{b})$ and LVV-H7 (c) on TSSS. ${ }^{*} p<0.05$ between groups (ANOVA followed by Bonferroni's multiple comparison test). ${ }^{* *} p<0.01$ between groups (ANOVA followed by Bonferroni's multiple comparison test). a

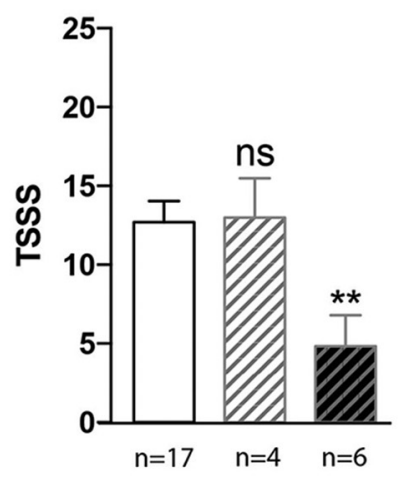

Pilocarpine $+\quad+\quad+$ Ang IV $(10 \mu \mathrm{M})$ - $\quad-\quad+$ Candesartan $(0.1 \mu \mathrm{M})-\quad+\quad+$

b

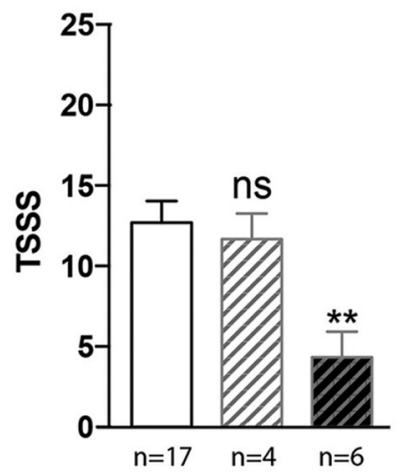

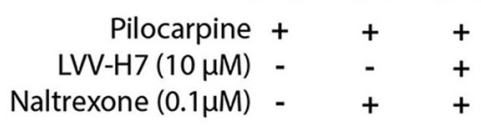

Figure 12. Angiotensin AT1 $(\boldsymbol{a})$ and $\mu / \kappa(\boldsymbol{b})$ receptors are not implicated in the anticonvulsive effect of Ang IV and LVV-H7 in the focal pilocarpine model. AT1 receptor antagonist candesartan $(\boldsymbol{a})$ and the opioid $\mu / \mathrm{k}$ receptor antagonist naltrexone (b) have no significant effect on seizure severity compared with the pilocarpine control group. Furthermore, pretreatment with candesartan or naltrexone does not abolish the anticonvulsive effect of Ang IV. ${ }^{* *} p<0.01$ compared with the pilocarpine control group (ANOVA followed by Bonferroni's multiple comparison test). ns, Not significant compared with the pilocarpine control group.

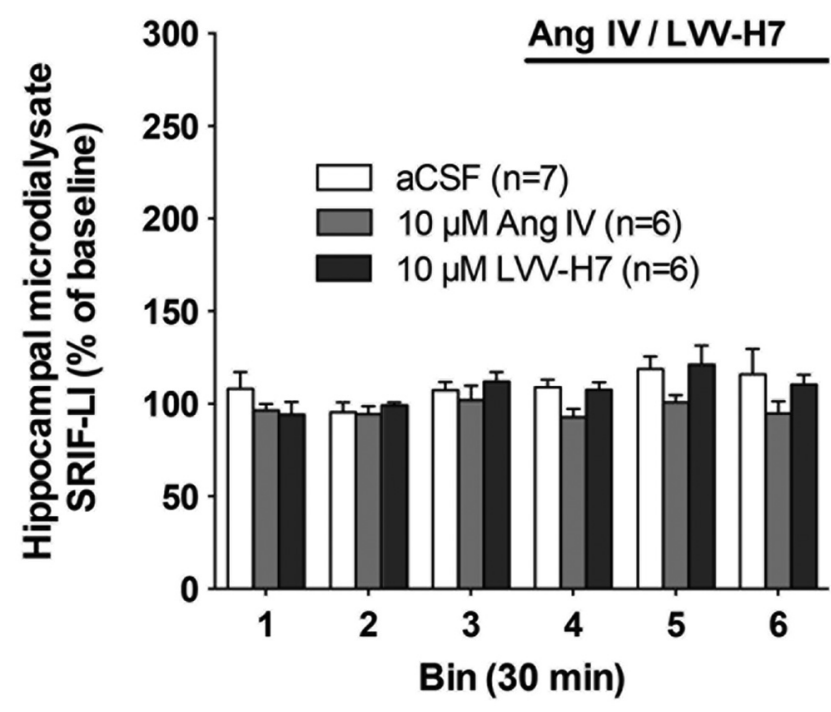

Figure 13. Administration of Ang IV and LVV-H7 does not decrease hippocampal SRIF concentration. Administration of Ang IV or LVV-H7 has no effect on SRIF concentration of hippocampal microdialysates (two-way ANOVA followed by Bonferroni's multiple comparison test: Ang IV or LVV-H7 vs aCSF control group). 
a
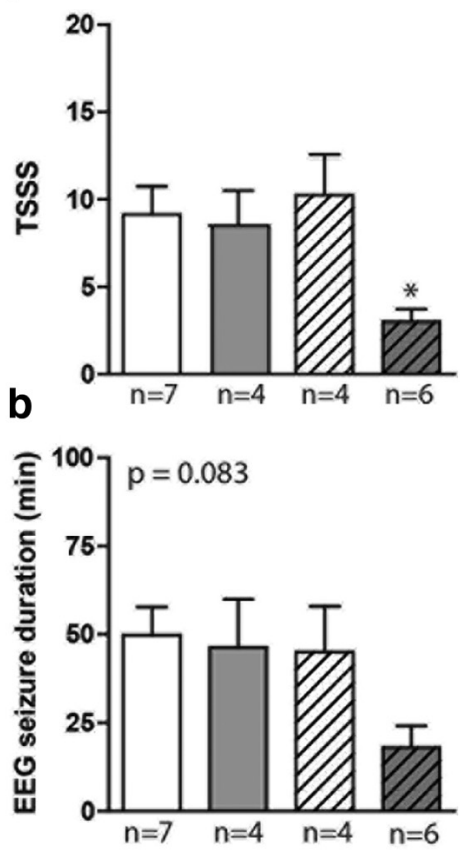

d

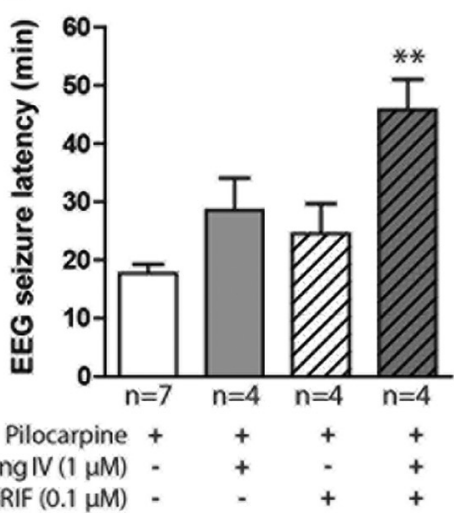

$\mathbf{f}$

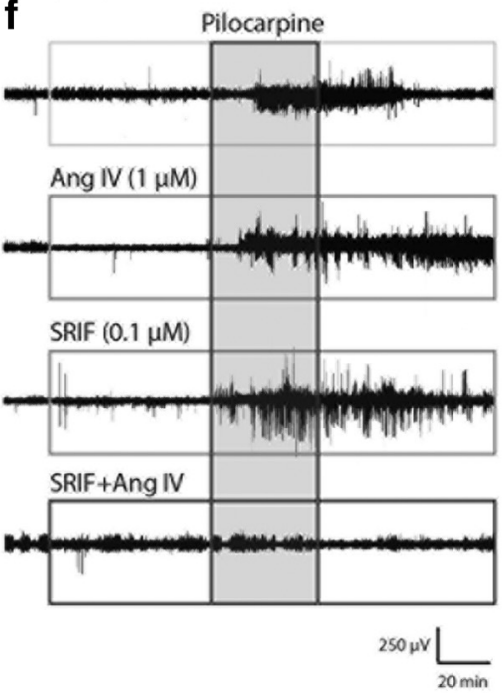

C
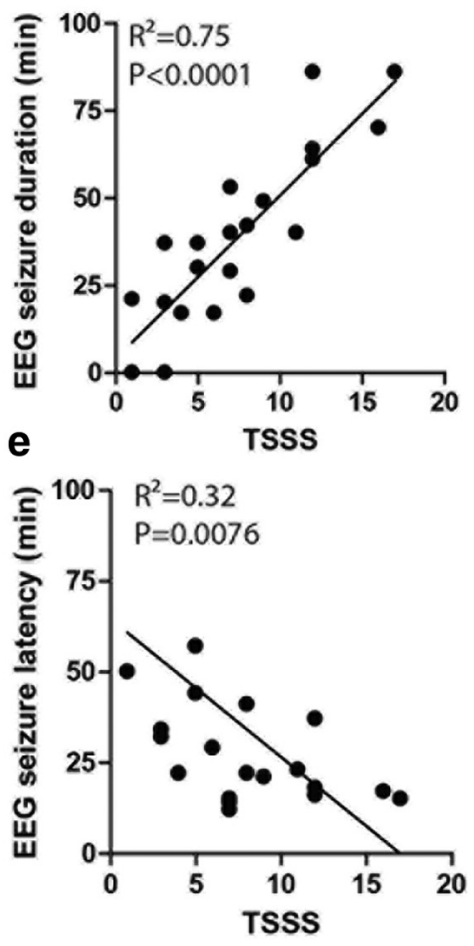

g

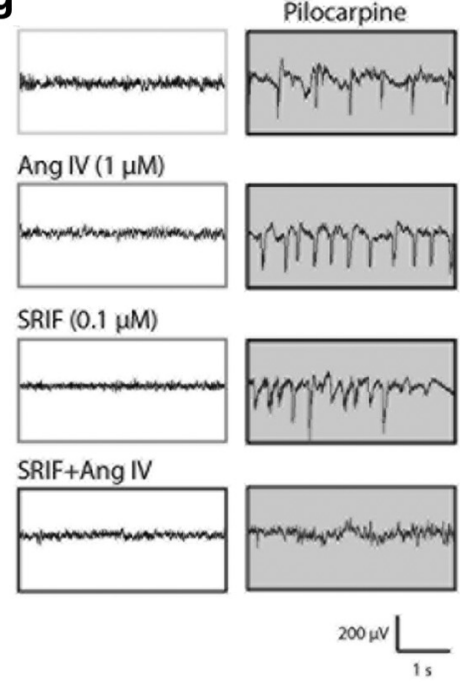

Figure 14. Ang IV potentiates the anticonvulsive effect of SRIF in the focal pilocarpine model. A combination of subthreshold concentrations (i.e., ineffective on pilocarpine-induced seizures) of Ang IV (1 $\mu \mathrm{M})$ and SRIF $(0.1 \mu \mathrm{M})$ significantly reduces behavioral seizures ( $\boldsymbol{a}$ ) compared with the pilocarpine control group. In rats treated with both Ang IV and SRIF, EEG seizure duration is not significantly different $(\boldsymbol{b})$, whereas the latency to first $\mathrm{EEG}$ seizure is significantly higher $(\boldsymbol{d})$ compared with the pilocarpine control.

(Sakurada et al., 1990; Barnes et al., 1995) or endopeptidase-24.15 and 24.16 (Dahms and Mentlein, 1992), may be more important for SRIF degradation. Consequently, we rule out the "enzyme hypothesis" as a mechanism of action in our limbic seizure model. Importantly, using immunogold electron microscopy, we further demonstrate that Ang IV increased in vivo the availability of membrane-associated sst2A receptors. Together, our results bring us to the conclusion that IRAP ligands favor a rapid recycling and resensitization of sst $2 \mathrm{~A}$ receptors following their internalization and enhance endogenous SRIF inhibitory effects on seizure activity by increasing the density of functional receptors at the plasma membrane. These results are in agreement with studies using the $\beta 2$ adrenergic receptor (Pippig et al., 1995; Vistein and Puthenveedu, 2013) or the Human G Protein-Coupled Receptor 17 (Daniele et al., 2011) demonstrating that recycled receptors resensitize rapidly.

In the hippocampal formation, SRIF interneurons and the sst $2 \mathrm{~A}$ receptor, which is highly expressed in the dendritic fields of granular and pyramidal cells, are well poised to regulate neuronal hyperexcitability (Johansson et al., 1984; Tallent and Qiu, 2008). Hilar SRIF inhibitory interneurons and their axons that terminate on the distal dendrites of granule cells are positioned to inhibit granule cells at the perforant path inputs, a major excitatory pathway to the hippocampus. SRIF fibers are present in the hilus, suggesting that SRIF neurons also modulate hilar neurons (Leranth et al., 1990; Lübke et al., 1998). SRIF axons are also localized throughout the CA1-CA3 regions, being enriched in stratum lacunosum moleculare (Johansson et al., 1984). Distinct inhibitory actions at the cellular level in rat CA1 pyramidal neurons were demonstrated for SRIF. It increases two different types of $\mathrm{K}^{+}$currents: the voltage-sensitive M-current (Moore et al., 1988; Schweitzer et al., 1990) and a voltage-insensitive leak current (Schweitzer et al., 1998). Postsyn-

$\leftarrow$

group. The TSSS is positively correlated with EEG seizure duration (c) and negatively correlated with EEG seizure latency $(\boldsymbol{e})$. Representative EEG traces are shown in $\boldsymbol{f}$, with $\boldsymbol{g}$ illustrating baseline EEG activity (left panels) and typical spike-wave activity $40 \mathrm{~min}$ following the onset of pilocarpine administration (right panels). ${ }^{*} p<0.05$ compared with the pilocarpine control group (ANOVA followed by Bonferroni's multiple comparison test). ${ }^{* *} p<0.01$ compared with the pilocarpine control group (ANOVA followed by Bonferroni's multiple comparison test). 

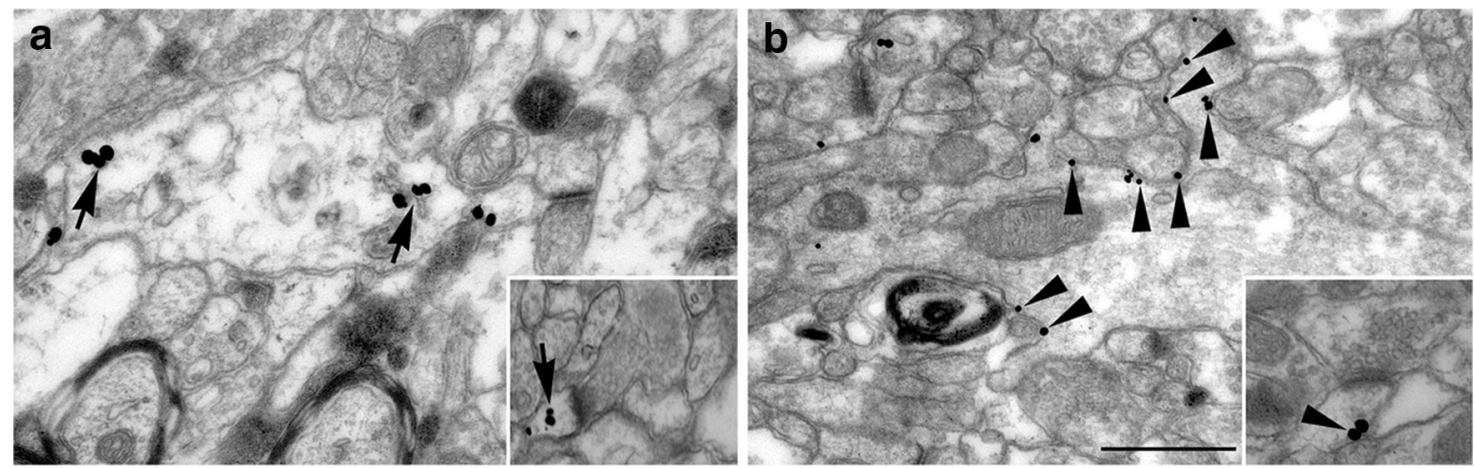

C

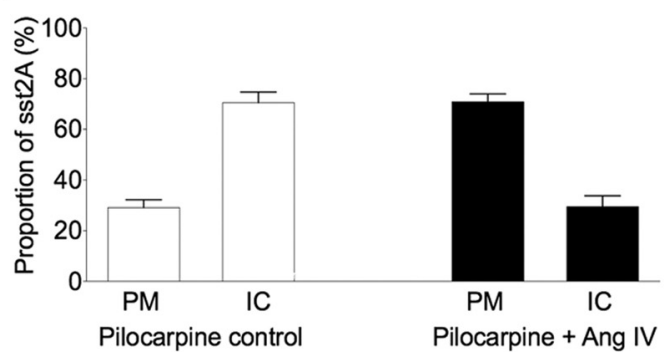

d

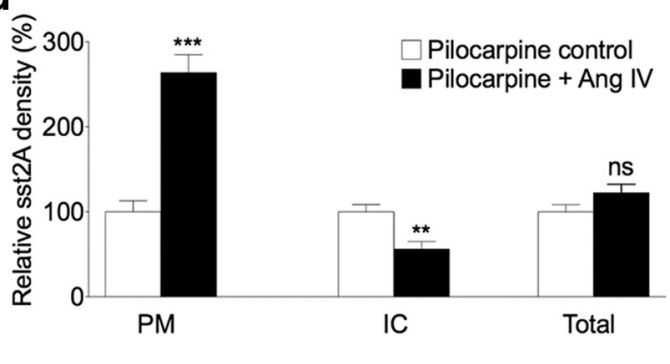

Figure 15. Ang IV increases in vivo the density of sst2A receptors at the plasma membrane in pilocarpine-treated rats. $\boldsymbol{a}, \boldsymbol{b}$, In pilocarpine control rats, many sst2A receptor immunoparticles are intracellular (arrows) in dendrites (a) and dendritic spines (a, inset) of CA1 pyramidal neurons. In the pilocarpine group, which received intrahippocampal perfusion of Ang IV, numerous sst2A receptor immunoparticles are located at the plasma membrane (arrowheads) of dendrites ( $\boldsymbol{b})$ and dendritic spines (b, inset) of CA1 pyramidal neurons. Scale bar, $500 \mathrm{~nm}$. $\boldsymbol{c}$, In pilocarpine control rats, the largest proportion of sst2A receptor immunoparticles are intracellular in CA1 pyramidal cell dendrites, only $28.6 \%$ of them are associated with the plasma membrane. By contrast, in the pilocarpine group treated with Ang IV, 70.5\% of sst2A receptor immunoparticles are at the plasma membrane of CA1 pyramidal cell dendrites. $\boldsymbol{d}$, Statistical analysis reveals that the density of immunoparticles is significantly higher at the plasma membrane and lower intracellularly in the Ang IV-treated pilocarpine group compared with the pilocarpine controls. The total number of immunoparticles is not different between the two groups. Ten dendrites/animal were analyzed in 3 control and Ang IV-treated rats. Values are expressed in relation to an arbitrary unit (100\%) of the control values. ${ }^{* *} p<0.01$ (Mann-Whitney U test). ${ }^{* * *} p<0.001$ (Mann-Whitney U test). ns, Not significant; IC, intracellular; PM, plasma membrane.

aptic hyperpolarization and reduced EPSCs of CA1-3 pyramidal neurons by SRIF have also been reported (Tallent and Siggins, 1997, 1999). Together, these studies and our present results emphasize the importance of the hippocampal somatostatinergic network, which includes the availability of functional sst2A receptors at the plasma membrane for dampening neuronal hyperexcitability.

Although beyond the scope of the present study, it would be of interest to decipher the mechanisms by which IRAP is able to regulate the recycling of the sst $2 \mathrm{~A}$ receptor. In $\mathrm{CHO}-\mathrm{K} 1$ and $\mathrm{HEK}$ 293 cells, iodinated Ang IV induced internalization of IRAP, which appears to be clathrin-mediated (Demaegdt et al., 2008). Ligand-induced internalization and recycling of IRAP have also been suggested in neurons (Fernando et al., 2008). In hippocampal cells treated with Ang IV, we did not observe a timedependent accumulation of IRAP immunoreactivity within intracytoplasmic vesicles. This suggests that intracellular stores of IRAP are constantly driven to the cell surface to replace internalized IRAP and that the IRAP exocytosis rate is higher in the presence of its ligands. Because internalized sst $2 \mathrm{~A}$ receptors travel through IRAP-containing vesicles, one can hypothesize that the rate of receptor exocytosis is indirectly dependent upon the presence of IRAP ligands (i.e., sst2A receptors recycle faster in cells or tissue incubated with Ang IV or LVV-H7). If this is the case, effects of IRAP ligands would not be specific for the sst2A receptor but could also modulate other types of receptors that internalize and recycle through an IRAP/TGN compartment. Most interestingly, Ang IV has been shown to reverse the kindlinginduced downregulation of dopaminergic D1 and D2 receptors in the basal ganglia (Tchekalarova et al., 2004), two receptors that are well known to internalize in neurons (Dumartin et al., 1998; Skinbjerg et al., 2010; Lane et al., 2012). Thus, IRAP ligands, in addition to their potential for modulating limbic seizures, might also represent appealing therapeutic tools in neurological diseases or following pharmacological treatments in which downregulation of GPCRs could occur (Bezard et al., 2001; Gainetdinov et al., 2004; Williams et al., 2013). Although the above described mechanism by which IRAP ligands could impact on sst $2 \mathrm{~A}$ receptor intracellular trafficking is a likely starting hypothesis, the cellular events involved could be difficult to decipher. In insulin-sensitive cells, IRAP trafficking itself is far from being understood, despite a large number of studies (Albiston et al., 2007). In addition, IRAP and the sst $2 \mathrm{~A}$ receptor both interact through their intracytoplasmic domain with several proteins involved in vesicle trafficking, tethering, and membrane anchoring (Albiston et al., 2007; Watson et al., 2008; Csaba et al., 2012). Interestingly, IRAP knockdown in adipocytes increases plasma membrane GLUT4 levels due to an increase of exocytosis (Jordens et al., 2010). Regarding our present results showing that IRAP knockdown increases the recycling of the receptor to the plasma membrane, it appears that IRAP could be a negative regulator of the exocytosis pathway in different cell types. Further studies in neuronal cells are mandatory to shed light on the molecular and cellular mechanisms implicated in this process.

In conclusion, the present study demonstrates that two structurally different peptidergic IRAP ligands protect against limbic seizures in rats. These anticonvulsive effects do not result from the inhibition of the enzymatic activity of IRAP and subsequent prevention of SRIF degradation. We demonstrate that IRAP, following ligand binding, trans-regulates the recycling process of the 
sst2A receptor and increases the availability of this inhibitory receptor at the plasma membrane. This represents a novel mechanism by which GPCR transmission can be regulated and further demonstrates that IRAP is a potential therapeutic target for the treatment of epilepsy. Whether IRAP could modulate the downregulation of other types of GPCRs, thus displaying additional therapeutic interests, will represent intriguing issues for future studies.

\section{References}

Albiston AL, Mustafa T, McDowall SG, Mendelsohn FA, Lee J, Chai SY (2003) AT4 receptor is insulin-regulated membrane aminopeptidase: potential mechanisms of memory enhancement. Trends Endocrinol Metab 14:72-77. CrossRef Medline

Albiston AL, Peck GR, Yeatman HR, Fernando R, Ye S, Chai SY (2007) Therapeutic targeting of insulin-regulated aminopeptidase: heads and tails? Pharmacol Ther 116:417-427. CrossRef Medline

Albiston AL, Diwakarla S, Fernando RN, Mountford SJ, Yeatman HR, Morgan B, Pham V, Holien JK, Parker MW, Thompson PE, Chai SY (2011) Identification and development of specific inhibitors for insulinregulated aminopeptidase as a new class of cognitive enhancers. Br J Pharmacol 164:37-47. CrossRef Medline

Aourz N, De Bundel D, Stragier B, Clinckers R, Portelli J, Michotte Y, Smolders I (2011) Rat hippocampal somatostatin sst3 and sst4 receptors mediate anticonvulsive effects in vivo: indications of functional interactions with sst2 receptors. Neuropharmacology 61:1327-1333. CrossRef Medline

Barnes K, Doherty S, Turner AJ (1995) Endopeptidase-24.11 is the integral membrane peptidase initiating degradation of somatostatin in the hippocampus. J Neurochem 64:1826-1832. CrossRef Medline

Bassant MH, Simon A, Poindessous-Jazat F, Csaba Z, Epelbaum J, Dournaud P (2005) Medial septal GABAergic neurons express the somatostatin sst2A receptor: functional consequences on unit firing and hippocampal theta. J Neurosci 25:2032-2041. CrossRef Medline

Bezard E, Brotchie JM, Gross CE (2001) Pathophysiology of levodopainduced dyskinesia: potential for new therapies. Nat Rev Neurosci 2:577588. CrossRef Medline

Chai SY, Fernando R, Peck G, Ye SY, Mendelsohn FA, Jenkins TA, Albiston AL (2004) The angiotensin IV/AT4 receptor. Cell Mol Life Sci 61:27282737. CrossRef Medline

Clynen E, Swijsen A, Raijmakers M, Hoogland G, Rigo JM (2014) Neuropeptides as targets for the development of anticonvulsant drugs. Mol Neurobiol 50:626-646. CrossRef Medline

Csaba Z, Bernard V, Helboe L, Bluet-Pajot MT, Bloch B, Epelbaum J, Dournaud P (2001) In vivo internalization of the somatostatin sst2A receptor in rat brain: evidence for translocation of cell-surface receptors into the endosomal recycling pathway. Mol Cell Neurosci 17:646-661. CrossRef Medline

Csaba Z, Simon A, Helboe L, Epelbaum J, Dournaud P (2003) Targeting sst2A receptor-expressing cells in the rat hypothalamus through in vivo agonist stimulation: neuroanatomical evidence for a major role of this subtype in mediating somatostatin functions. Endocrinology 144:15641573. CrossRef Medline

Csaba Z, Richichi C, Bernard V, Epelbaum J, Vezzani A, Dournaud P (2004) Plasticity of somatostatin and somatostatin sst2A receptors in the rat dentate gyrus during kindling epileptogenesis. Eur J Neurosci 19:25312538. CrossRef Medline

Csaba Z, Pirker S, Lelouvier B, Simon A, Videau C, Epelbaum J, Czech T, Baumgartner C, Sperk G, Dournaud P (2005) Somatostatin receptor type 2 undergoes plastic changes in the human epileptic dentate gyrus. J Neuropathol Exp Neurol 64:956-969. CrossRef Medline

Csaba Z, Lelouvier B, Viollet C, El Ghouzzi V, Toyama K, Videau C, Bernard V, Dournaud P (2007) Activated somatostatin type 2 receptors traffic in vivo in central neurons from dendrites to the trans Golgi before recycling. Traffic 8:820-834. CrossRef Medline

Csaba Z, Peineau S, Dournaud P (2012) Molecular mechanisms of somatostatin receptor trafficking. J Mol Endocrinol 48:R1-R12. CrossRef Medline

Dahms P, Mentlein R (1992) Purification of the main somatostatindegrading proteases from rat and pig brains, their action on other neuro- peptides, and their identification as endopeptidases 24.15 and 24.16. Eur J Biochem 208:145-154. CrossRef Medline

Daniele S, Trincavelli ML, Gabelloni P, Lecca D, Rosa P, Abbracchio MP, Martini C (2011) Agonist-induced desensitization/resensitization of human G-protein-coupled receptor 17: a functional cross-talk between purinergic and cysteinyl-leukotriene ligands. J Pharmacol Exp Ther 338: 559-567. CrossRef Medline

De Bundel D, Smolders I, Yang R, Albiston AL, Michotte Y, Chai SY (2009) Angiotensin IV and LVV-haemorphin 7 enhance spatial working memory in rats: effects on hippocampal glucose levels and blood flow. Neurobiol Learn Mem 92:19-26. CrossRef Medline

De Bundel D, Demaegdt H, Lahoutte T, Caveliers V, Kersemans K, Ceulemans AG, Vauquelin G, Clinckers R, Vanderheyden P, Michotte Y, Smolders I (2010) Involvement of the AT1 receptor subtype in the effects of angiotensin IV and LVV-haemorphin 7 on hippocampal neurotransmitter levels and spatial working memory. J Neurochem 112:1223-1234. CrossRef Medline

Demaegdt H, Smitz L, De Backer JP, Le MT, Bauwens M, Szemenyei E, Tóth G, Michotte Y, Vanderheyden P, Vauquelin G (2008) Translocation of the insulin-regulated aminopeptidase to the cell surface: detection by radioligand binding. Br J Pharmacol 154:872-881. CrossRef Medline

Dobolyi A, Kékesi KA, Juhász G, Székely AD, Lovas G, Kovács Z (2014) Receptors of peptides as therapeutic targets in epilepsy research. Curr Med Chem 21:764-787. CrossRef Medline

Dournaud P, Gu YZ, Schonbrunn A, Mazella J, Tannenbaum GS, Beaudet A (1996) Localization of the somatostatin receptor SST2A in rat brain using a specific anti-peptide antibody. J Neurosci 16:4468-4478. Medline

Dournaud P, Boudin H, Schonbrunn A, Tannenbaum GS, Beaudet A (1998) Interrelationships between somatostatin sst $2 \mathrm{~A}$ receptors and somatostatin-containing axons in rat brain: evidence for regulation of cell surface receptors by endogenous somatostatin. J Neurosci 18:1056-1071. Medline

Dumartin B, Caillé I, Gonon F, Bloch B (1998) Internalization of D1 dopamine receptor in striatal neurons in vivo as evidence of activation by dopamine agonists. J Neurosci 18:1650-1661. Medline

Fernando RN, Larm J, Albiston AL, Chai SY (2005) Distribution and cellular localization of insulin-regulated aminopeptidase in the rat central nervous system. J Comp Neurol 487:372-390. CrossRef Medline

Fernando RN, Luff SE, Albiston AL, Chai SY (2007) Sub-cellular localization of insulin-regulated membrane aminopeptidase, IRAP to vesicles in neurons. J Neurochem 102:967-976. CrossRef Medline

Fernando RN, Albiston AL, Chai SY (2008) The insulin-regulated aminopeptidase IRAP is colocalised with GLUT4 in the mouse hippocampus: potential role in modulation of glucose uptake in neurones? Eur J Neurosci 28:588-598. CrossRef Medline

Gainetdinov RR, Premont RT, Bohn LM, Lefkowitz RJ, Caron MG (2004) Desensitization of $\mathrm{G}$ protein-coupled receptors and neuronal functions. Annu Rev Neurosci 27:107-144. CrossRef Medline

Irannejad R, Tomshine JC, Tomshine JR, Chevalier M, Mahoney JP, Steyaert J, Rasmussen SG, Sunahara RK, El-Samad H, Huang B, von Zastrow M (2013) Conformational biosensors reveal GPCR signalling from endosomes. Nature 495:534-538. CrossRef Medline

Johansson O, Hökfelt T, Elde RP (1984) Immunohistochemical distribution of somatostatin-like immunoreactivity in the central nervous system of the adult rat. Neuroscience 13:265-339. CrossRef Medline

Jordens I, Molle D, Xiong W, Keller SR, McGraw TE (2010) Insulinregulated aminopeptidase is a key regulator of GLUT4 trafficking by controlling the sorting of GLUT4 from endosomes to specialized insulinregulated vesicles. Mol Biol Cell 21:2034-2044. CrossRef Medline

Keller SR (2003) The insulin-regulated aminopeptidase: a companion and regulator of GLUT4. Front Biosci 8:410-420.

Lane DA, Chan J, Fitzgerald ML, Kearn CS, Mackie K, Pickel VM (2012) Quinpirole elicits differential in vivo changes in the presynaptic and postsynaptic distributions of dopamine $\mathrm{D}(2)$ receptors in mouse striatum: relation to cannabinoid-1 $\left(\mathrm{CB}_{1}\right)$ receptor targeting. Psychopharmacology (Berl) 221:101-113. CrossRef Medline

Lee J, Chai SY, Mendelsohn FA, Morris MJ, Allen AM (2001) Potentiation of cholinergic transmission in the rat hippocampus by angiotensin IV and LVV-hemorphin-7. Neuropharmacology 40:618-623. CrossRef Medline

Lelouvier B, Tamagno G, Kaindl AM, Roland A, Lelievre V, Le Verche V, Loudes C, Gressens P, Faivre-Baumann A, Lenkei Z, Dournaud P (2008) Dynamics of somatostatin type $2 \mathrm{~A}$ receptor cargoes in living hippocampal neurons. J Neurosci 28:4336-4349. CrossRef Medline 
Leranth C, Malcolm AJ, Frotscher M (1990) Afferent and efferent synaptic connections of somatostatin-immunoreactive neurons in the rat fascia dentata. J Comp Neurol 295:111-122. CrossRef Medline

Leto D, Saltiel AR (2012) Regulation of glucose transport by insulin: traffic control of GLUT4. Nat Rev Mol Cell Biol 13:383-396. CrossRef Medline

Loyens E, Schallier A, Chai SY, De Bundel D, Vanderheyden P, Michotte Y, Smolders I (2011) Deletion of insulin-regulated aminopeptidase in mice decreases susceptibility to pentylenetetrazol-induced generalized seizures. Seizure 20:602-605. CrossRef Medline

Lübke J, Frotscher M, Spruston N (1998) Specialized electrophysiological properties of anatomically identified neurons in the hilar region of the rat fascia dentata. J Neurophysiol 79:1518-1534. Medline

Matsumoto H, Nagasaka T, Hattori A, Rogi T, Tsuruoka N, Mizutani S, Tsujimoto M (2001) Expression of placental leucine aminopeptidase/ oxytocinase in neuronal cells and its action on neuronal peptides. Eur J Biochem 268:3259-3266. CrossRef Medline

Meurs A, Clinckers R, Ebinger G, Michotte Y, Smolders I (2008) Seizure activity and changes in hippocampal extracellular glutamate, GABA, dopamine and serotonin. Epilepsy Res 78:50-59. CrossRef Medline

Moore SD, Madamba SG, Joëls M, Siggins GR (1988) Somatostatin augments the M-current in hippocampal neurons. Science 239:278-280. CrossRef Medline

Olias G, Viollet C, Kusserow H, Epelbaum J, Meyerhof W (2004) Regulation and function of somatostatin receptors. J Neurochem 89:1057-1091. CrossRef Medline

Peineau S, Potier B, Petit F, Dournaud P, Epelbaum J, Gardette R (2003) AMPA-sst2 somatostatin receptor interaction in rat hypothalamus requires activation of NMDA and/or metabotropic glutamate receptors and depends on intracellular calcium. J Physiol 546:101-117. CrossRef Medline

Pippig S, Andexinger S, Lohse MJ (1995) Sequestration and recycling of beta 2-adrenergic receptors permit receptor resensitization. Mol Pharmacol 47:666-676. Medline

Sakurada C, Yokosawa H, Ishii S (1990) The degradation of somatostatin by synaptic membrane of rat hippocampus is initiated by endopeptidase24.11. Peptides 11:287-292. CrossRef Medline

Saveanu L, van Endert P (2012) The role of insulin-regulated aminopeptidase in MHC class I antigen presentation. Front Immunol 3:57. CrossRef Medline

Schindler M, Sellers LA, Humphrey PP, Emson PC (1997) Immunohistochemical localization of the somatostatin SST2(A) receptor in the rat brain and spinal cord. Neuroscience 76:225-240. CrossRef Medline

Schweitzer P, Madamba S, Siggins GR (1990) Arachidonic acid metabolites as mediators of somatostatin-induced increase of neuronal M-current. Nature 346:464-467. CrossRef Medline

Schweitzer P, Madamba SG, Siggins GR (1998) Somatostatin increases a voltage-insensitive $\mathrm{K}^{+}$conductance in rat CA1 hippocampal neurons. J Neurophysiol 79:1230-1238. Medline

Skinbjerg M, Liow JS, Seneca N, Hong J, Lu S, Thorsell A, Heilig M, Pike VW, Halldin C, Sibley DR, Innis RB (2010) D2 dopamine receptor internalization prolongs the decrease of radioligand binding after amphetamine: a PET study in a receptor internalization-deficient mouse model. Neuroimage 50:1402-1407. CrossRef Medline
Stragier B, Clinckers R, Meurs A, De Bundel D, Sarre S, Ebinger G, Michotte $\mathrm{Y}$, Smolders I (2006) Involvement of the somatostatin-2 receptor in the anti-convulsant effect of angiotensin IV against pilocarpine-induced limbic seizures in rats. J Neurochem 98:1100-1113. CrossRef Medline

Stumm RK, Zhou C, Schulz S, Endres M, Kronenberg G, Allen JP, Tulipano G, Höllt V (2004) Somatostatin receptor 2 is activated in cortical neurons and contributes to neurodegeneration after focal ischemia. J Neurosci 24:11404-11415. CrossRef Medline

Tallent MK, Qiu C (2008) Somatostatin: an endogenous antiepileptic. Mol Cell Endocrinol 286:96-103. CrossRef Medline

Tallent MK, Siggins GR (1997) Somatostatin depresses excitatory but not inhibitory neurotransmission in rat CA1 hippocampus. J Neurophysiol 78:3008-3018. Medline

Tallent MK, Siggins GR (1999) Somatostatin acts in CA1 and CA3 to reduce hippocampal epileptiform activity. J Neurophysiol 81:1626-1635. Medline

Tchekalarova J, Kambourova T, Georgiev V (2001) Effects of angiotensin III and angiotensin IV on pentylenetetrazol seizure susceptibility (threshold and kindling): interaction with adenosine $\mathrm{A}(1)$ receptors. Brain Res Bull 56:87-91. CrossRef Medline

Tchekalarova J, Sotiriou E, Angelatou F (2004) Down-regulation of dopamine D1 and D2 receptors in the basal ganglia of PTZ kindling model of epilepsy: effects of angiotensin IV. Brain Res 1024:159-166. CrossRef Medline

Vanderheyden PM (2009) From angiotensin IV binding site to AT4 receptor. Mol Cell Endocrinol 302:159-166. CrossRef Medline

Vezzani A, Hoyer D (1999) Brain somatostatin: a candidate inhibitory role in seizures and epileptogenesis. Eur J Neurosci 11:3767-3776. CrossRef Medline

Vistein R, Puthenveedu MA (2013) Reprogramming of G protein-coupled receptor recycling and signaling by a kinase switch. Proc Natl Acad Sci U S A 110:15289-15294. CrossRef Medline

von Zastrow M, Williams JT (2012) Modulating neuromodulation by receptor membrane traffic in the endocytic pathway. Neuron 76:22-32. CrossRef Medline

Watson RT, Hou JC, Pessin JE (2008) Recycling of IRAP from the plasma membrane back to the insulin-responsive compartment requires the Q-SNARE syntaxin 6 but not the GGA clathrin adaptors. J Cell Sci 121: 1243-1251. CrossRef Medline

Williams JT, Ingram SL, Henderson G, Chavkin C, von Zastrow M, Schulz S, Koch T, Evans CJ, Christie MJ (2013) Regulation of mu-opioid receptors: desensitization, phosphorylation, internalization, and tolerance. Pharmacol Rev 65:223-254. CrossRef Medline

Wright JW, Harding JW (2011) Brain renin-angiotensin: a new look at an old system. Prog Neurobiol 95:49-67. CrossRef Medline

Yang R, Smolders I, De Bundel D, Fouyn R, Halberg M, Demaegdt H, Vanderheyden P, Dupont AG (2008) Brain and peripheral angiotensin II type 1 receptors mediate renal vasoconstrictor and blood pressure responses to angiotensin IV in the rat. J Hypertens 26:998-1007. CrossRef Medline

Zhao Q, Garreau I, Sannier F, Piot JM (1997) Opioid peptides derived from hemoglobin: hemorphins. Biopolymers 43:75-98. CrossRef Medline 